\title{
Birinci Dünya Savaşı'nda Pontusçu Rum Çetelerinin Bafra ve Çevresindeki Faaliyetleri (1914-1918)
}

\author{
Cemal Sezer* \\ (ORCID ID: 0000-0002-5143-4023) \\ Makale Gönderim Tarihi \\ 16.10.2020 \\ Makale Kabul Tarihi \\ 03.03.2021
}

\section{Atıf Bilgisi/Reference Information}

Chicago: Sezer, C., "Birinci Dünya Savaşı'nda Pontusçu Rum Çetelerinin Bafra ve Çevresindeki Faaliyetleri (1914-1918)", Vakanüvis-Uluslararası Tarih Araştırmaları Dergisi, 6/1 (2021): 349-380.

APA: Sezer, C. (2021). Birinci Dünya Savaşı'nda Pontusçu Rum Çetelerinin Bafra ve Çevresindeki Faaliyetleri (1914-1918). Vakanüvis-Uluslararası Tarih Araştırmaları Dergisi, 6 (1) , 349-380.

\section{Öz}

Osmanlı Devleti'nin Birinci Dünya Savaşı́nda İttifak Devletlerinin yanında yer almasıyla Anadolu'da bağımsız bir devlet kurmak isteyen Ermeni ve Rumların kendilerini gösterdikleri yollardan biri de çetecilik faaliyetleri olmuştur. Ermeni ve Rumlar, çetecilik faaliyetleriyle Osmanlı Devleti'ni cephe gerisinde zor durumda bırakıp İtilaf Devletlerini memnun ederek hedeflerine ulaşabileceklerini düşündüler. Bu amaçla Bafra'daki Rumlar, savaş sırasında vatandaşı oldukları Osmanlı Devleti'nin seferberlik çağrısına uymayarak Rum çetelerine katıldılar. Samsun merkezli Kastamonu'dan Batum'a hatta Erzincan'ın bir kısmını içine alacak şekilde bir Pontus Devleti kurma amacına hizmet eden bu çetelerin yoğun olarak faaliyet yürüttüğü coğrafyalardan birisi de Canik (Samsun) sancağına bağı Bafra kazası olmuştur. Bafra ve çevresindeki çeteler; Bafra, Alaçam, Kavak ve Samsun bölgeleri arasında kalan Nebyan dağlarını merkez edindiler. Bafra adliye kayıtlarına göre Rum çetelerinin faaliyetleri sonucunda; öldürme, yaralama, gasp, yol kesme, hırsızlık, yağmalama gibi suçlar işlenmiştir. Dolayısıyla amaç ve yöntem açısından

\footnotetext{
* Doç. Dr., Bolu Abant İzzet Baysal Üniversitesi, Fen-Edebiyat Fakültesi, Tarih Bölümü, sezer_c@ibu.edu.tr.
}

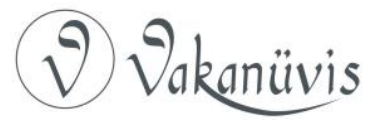


aralarında bir farklılık bulunmayan Ermeni çetelerin yaptıkları katliamların bir benzerini Karadeniz'de Pontusçu Rum çeteleri gerçekleştirmiştir. Bu çalışmada; Pontusçu Rum çetelerinin Bafra ve çevresindeki faaliyetleri Osmanlı arşiv belgeleri referans verilerek ve bununla ilgili çalışmalar göz önünde bulundurularak incelenecektir. Böylece Birinci Dünya Savaşı sırasında Osmanlı topraklarının diğer yerlerinde olduğu gibi Bafra ve çevresinde Türklere yönelik bir katliamın yaşandığı gerçeği açıklanacaktır. Bafra ve çevresi Pontusçu faaliyetlerde önemli bir merkez olmuştur. Bu çalışmanın amacı Bafra ve çevresindeki Pontusçu faaliyetler hakkında bazı önemli bilgileri ortaya çıkarmak ve literatüre katkıda bulunmaktır.

Anahtar Kelimeler: Birinci Dünya Savaşı, Bafra, Rum, Pontus, Çete

\section{Activities of Pontus Greek Gangs in and Around Bafra in the First World War} (1914-1918)

\section{Abstract}

When the Ottoman Empire stood alongside the Central Powers during the First World War, Armenians and Greeks, who wanted to establish independent states in Anatolia, started ganging activities in the region. Armenians and Greeks believed that they could reach their aim by putting the Ottoman Empire in a difficult position behind-the-lines through ganging and supporting the Allies; for this purpose, the Greeks in Bafra didn't obey Ottoman's call for mobilization although they were citizens of the Empire during the War. They instead joined the Greek gangs. The district of Bafra, under Canik (Samsun) Sanjak, was one of the locations where these gangs carried outserious activities for the purpose of establishing a Pontus State; the so-called State would be located in Samsun (as the center), covering an area including Kastamonu, Batum and a part of Erzincan. Nebyan Mountains located among Bafra, Alaçam, Kavak and Samsun regions were centers for gangs in and around Bafra. According to the registrations of the Bafra courthouse, the crimes of murder, injury, extortion, highway robbery, theft, plunder were committed by the Greek gangs. The crimes of Pontus Greek gangs in the Black Sea Region were similar to those of the Armenian gangs in terms of purpose and method. The activities of Pontus Greek gangs in and around Bafra will be analyzed on the basis of the references from Ottoman archive documents and related studies in the literature. The truth that Turks were killed in a cruel way in and around Bafra, similar to the cruel activities in the other areas in the Ottoman Empire during the First World War will be explained in this study. Bafra and the area surrounding Bafra were important centers for Pontus activities. The aim of this

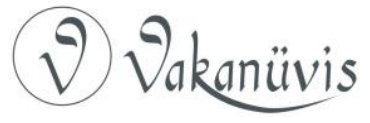


study is to discover some important information about Pontus activities in and around Bafra and to contribute to the literature.

Keywords: The First World War, Bafra, Greek, Pontus, Gang

\section{Giriş}

Osmanlı döneminde Canik bölgesi; Vezirköprü, Havza ve Ladik dışında Samsun ile Ordu arasındaki kalan bölgeye verilen isimdir. XV. ve XVI. yüzyıllarda sancağın kazaları Samsun, Bafra, Kavak, Arım (bugünkü Çarşamba'ya yakın yer), Terme, Ünye ve Satılmış (Fatsa, Korgan ve civarı) bölgeleriydi. XVII. yüzyılda sancağın kaza sayısı artmış, örneğin Bafra'ya bağlı Alaçam nahiyesi kaza olmuştur ${ }^{1}$. 1830-1831 yıllarında Sivas eyaletine bağlı olan Canik sancağı, 1846-1847'deki idari taksimat ile Trabzon eyaletine, 1871 'de kabul edilen İdare-i Umumiye Vilayet Nizamnamesiyle 1872 'de müstakil hale gelmiştir. 1877 yılında Trabzon vilayetine bağlansa da², Mart 1910 tarihinde tekrar müstakil sancağa dönüşmüştür. Böylece 1910 itibariyle Canik sancağı, Samsun merkez olmak üzere Bafra, Çarşamba, Fatsa, Terme ve Ünye kazalarından meydana gelmiştir. Ayrıca merkez Samsun'a Kavak, Bafra'ya Alaçam ve Ünye'ye Karakuş nahiyeleri bağlıdır³.

1890 yılında Canik sancağında 214.135 Müslüman, 77.000 Rum, 269.565 Ermeni, 250 Yahudi ve 150 yabancı yaşamaktadır ${ }^{4}$. 1904'te ise 227.424 Müslüman, 72.653 Rum ve 20.002 Ermeni olmak üzere toplam 320.710 nüfusun \%71'i Müslümanlardan, \%22,7'si Rumlardan oluşmaktadır ${ }^{5}$ 1914 sayımına göre de Samsun (merkez), Ünye, Bafra, Fatsa, Çarşamba, Terme kazalarından meydana gelen Canik sancağında;

\footnotetext{
1 Mehmet Öz, "Samsun", Türkiye Diyanet Vakfı İslâm Ansiklopedisi, Cilt: 36, İstanbul 2009, s. 86.

2 Rıza Karagöz, "Canik'in İdarî Yapısı ve İdarecileri”, Ilkçağdan Cumhuriyete Canik, Ed. Cevdet Yılmaz, Samsun 2011, s. 130-131.

${ }^{3}$ Karagöz, a.g.m., s. 133; Rıza Karagöz, "II. Meşrutiyet Döneminde Canik Sancağında İdari Yapılanma”, Geçmişten Geleceğe Samsun, Yay. Haz. Cevdet Yılmaz, Samsun 2006, s. 67, 69.

${ }^{4}$ M. Emin Yolalıcı, XIX. Yüzyılda Canik (Samsun) Sancağı'nın Sosyal ve Ekonomik Yapısı, Ankara 1998, s. 30.

5 Öz, a.g.m., s. 86.
}

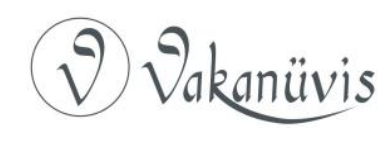


mevcut 393.340 kişiden oluşan nüfusun 265.950'si Müslüman, 98.739'u Rum, 27.319'u Ermeni olup geriye kalanlar Yahudi, Protestan, Keldani ve yabancılardan meydana gelmektedir. Aynı yılın Bafra'daki nüfus yapısı ise şöyleydi: 48.944 Müslüman, 30.838 Rum, 1.735 Ermeni, 23 yabancı olmak üzere toplam 81.540'tır6.

XIX. yüzyılın ikinci yarısına gelindiğinde Rumlar, Canik sancağında ekonomik olarak güçlenmiş ve kendi burjuvazisini ortaya çıkarmışlardı. Özellikle Rusya ve İran'la sürdürülen ticari ilişkiler Rum burjuvazisinin hâkimiyetinde gerçekleşmiştir. Ayrıca bölgenin en önemli tarım ürünü olan tütün ile fındık üretimi ve kıyı taşımacılı̆ıında da Rumlar söz sahibi olmuşlardır. Rum tüccarların ekonomik olarak gelişmesi kendisini yerel düzeyde de göstermiştir. Yedi üyeli Samsun Belediye Meclisi'nin altısı; Samsun Ticaret Odası'nın sekiz üyesinin dördü7, Ziraat Meclis üyelerinden altısı Rumlardan ikisi Türklerden oluşmaktaydı․

XVIII. yüzyılın sonlarından itibaren Fransa'da ortaya çıkan milliyetçiliğin Avrupa'da yayılmaya başlamasıyla, Osmanlı coğrafyası da etkilenmiştir. Illk önce Sırplar nezdinde başlayan ayaklanmalar ardından Yunanlara sıçramıştır. Başlangıçta bağımsız bir devlet kurmak, ardından Bizans Devleti'ni yeniden oluşturmak için Yunanlar, teşkilatlanmaya başlamışlardır. Kurdukları ilk cemiyet, Filiki Eterya'dır ${ }^{9}$. Cemiyetin başlıca amacı Yunanların bağımsızlığını sağladıktan sonra Akdeniz adaları ve İstanbul'u da içine alacak şekilde Megali İdea'yı gerçekleştirmektir. Gerçekleştirilmek istenen hedefler içerisinde bir

\footnotetext{
${ }^{6}$ Arşiv Belgeleriyle Ermeni Faaliyetleri 1914-1918, Cilt: I, Haz. Ahmet Tetik, Ankara 2005, s. 643.

7 Mustafa Balcıoğlu, "Birinci Dünya Savaşı Sırasında Karadeniz'de Rum Faaliyetleri ve Sivil Tepki", Osmanlı Tarihi Araştırma ve Uygulama Merkezi Dergisi, Sayı: 4, Ankara 1993, s. 92; Bünyamin Kocaoğlu, Millî Mücadele Yıllarında 15. Fırkanın Samsun'daki Faaliyetleri (1919-1921), Samsun 2012, s. 90.

8 Stefanos Yerasimos, Milliyetler ve Sınırlar Balkanlar, Kafkasya ve Orta-Doğu, İstanbul 2000, s. 354; Balcıoğlu, a.g.m., s. 92.

9 Osmanlı Devleti'ndeki Rumların silahlanması için propaganda faaliyetlerinde bulunan Cemiyet, 1814 yılında Odesa'da kurulmuştur. 1821 yılında başlayan Yunan İsyanı'nın liderliğini yapan Alexandros Ypsilantis, isyan sırasında Cemiyetin başında bulunmaktaydı. Bkz. Yüksel Küçüker, Tarihî Arka Planıyla Pontus Meselesi ve Yabancı Basına Yansımaları, Ankara 2019, s. 59.
}

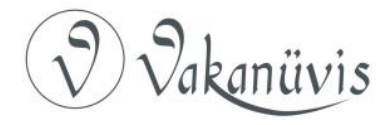


Pontus $^{10}$ Rum Devleti kurmak da bulunmaktaydı ${ }^{11}$. Merkezi Samsun olacak olan bu devletin sınırları; Batum'un kuzeyinden Inebolu'nun batısına kadar olan Rize, Trabzon, Ordu, Sinop, Kastamonu, Çankırı, Yozgat, Sivas, Gümüşhane, Karahisar-i Şarki (Şebinkarahisar), Tokat, Amasya, Çorum sancaklarının tamamı ve Erzincan sancağının bir bölümünü kapsıyordu ${ }^{12}$.

1904 yılında Amerikalı din görevlisi Klematyos'un girişimleriyle Inebolu'da Pontus Cemiyeti ${ }^{13}$, yine aynı yıl Merzifon Amerikan Koleji'ndeki Rum öğrenciler, "Rum İrfanperver" ve "Pontus" adında iki kulüp kurmuşlar, ardından üçüncüsü olarak "Musiki" kısmını oluşturmuşlardır. Daha sonra kurulan kulüpler "Pontus Cemiyeti" adı

10 "Pontos" ismi ilk olarak Karadeniz kıyılarında yaşayan ve yabancılara iyi davranmayan vahşi kabilelere verilen bir isimdir. Grekler, bölgede koloniler kurmaya başlayınca pekiyi karşılanmadıkları için Karadeniz'e "Pontos Axeinos veya Axenos (konuk/yabancı sevmeyen deniz)" demişlerdir. Fakat zamanla zenginleşince buranın ismini değiştirerek "Pontos Euxenos (Konuksever Deniz)"; Grek, Latin ve Ermeni yazarlar ise Pontos yani "Deniz" adını kullanmışlardır. Bkz. Mehmet Tezcan, "Pontos Krallığı (M.Ö. III-M.S. IV Yüzyıl)", Başlangıçtan Günümüze Pontus Sorunu, Ed. Veysel Usta, Ankara 2007, s. 77-78. MÖ. 298- MÖ. 63 yılları arasında varlık gösteren Pontos Krallığı ile Pontus Rum İmparatorluğu (1204-1261) arasında hiçbir ilişki ve bağlantı bulunmamaktadır. Amaç kurulacak yeni bir Rum devletinin tarihsel bağlantılarını ortaya koymaya çalışmaktadır. Örneğin Pontos Krallığı'nın merkezi sırasıyla Amasya, Sinop ve geçici bir süre için Bergama olmuştur. Trabzon Rum İmparatorluğu'nun ise adından da anlaşılacağı üzere Trabzon'dur. Daha sonra yeniden kurulmak istenen devletin merkezi ise Samsun olmuştur. Bkz. Mehmet Goloğlu, Anadolu'nun Millî Devleti Pontos, Ankara 1973, s. XVI. Bölgede Finikeliler, Asurlular, Kimriler, İskitler, Persler, Araplar, Cenevizliler, Venedikliler, Romalılar, Yunanlar, Moğollar, Selçuklular etkili olmuş ve yerel halkla kaynaşmışlardır. Bkz. Goloğlu, a.g.e., s. XVIII-XIX. Yerel halkın kimliğine bakıldığında ise Yunanlıktan ziyade bazılarının Türk asıllı oldukları görülmektedir. Dolayısıyla arması Ayyıldız olan ilk Pontos devletinin kralları tarihçilere göre İranlı ya da yerli prenslerden oluşmaktadır. Kesin olan bir şey var ise de, o da Yunan olmamalarıdır. Fakat Pontos kralları gelişmeye açık olduklarından Yunan kültür ve uygarlığına hayran olup temsilcilerini saraylarında ağırlamışlar; hatta Yunan prenseslerle evlenmişledir. Yunanların serbest olarak ticaret yapmalarına olanak sağlamışlardır. Böylece Yunan dili, kültürü ve uygarlığı yerli halkla kaynaşmıştır. Doğu Karadeniz bölgesinde Yunanca'nın hâkim dil olmayıp içerisinde Yunanca'nın da olduğu yerli dillerin karışımından çıkması, bu durumun bir göstergesidir. Geniş bilgi için bkz. Goloğlu, a.g.e., s. 78-104.

${ }^{11}$ Pontus Meselesi, Haz. Yılmaz Kurt, Ankara 1995, s. 31.

12 Pontus Meselesi, s. 61.

${ }^{13}$ Balcıoğlu, a.g.m., s. 92.

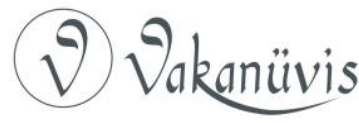


altında birleştirilmiştir. Genişlemeye devam eden Rum teşkilatlanması 1908 'de Samsun'da "Rum Teceddüt ve ihya Cemiyeti"den başka silahlı bir cemiyet olarak "Müdafaa-i Meşruta" yı meydana getirmişlerdir. Müdafaa-i Meşruta Cemiyeti'nin Ünye, Fatsa, Kavak, İnebolu, Havza, Çarşamba, Bafra, Sinop, Kayseri, Kırşehir, Ürgüp ve Tokat'ta şubeleri vard $1^{14}$. "Samsun Rum Muhacirin Cemiyeti", "Pontus Idman Kulübü", "İrfanperver Kulübü", "Mukaddes Rum Anadolu Cemiyeti”, Samsun'da varlıklarını sürdüren diğer cemiyetlerdir ${ }^{15}$.

Teşkilatlanmaya başladıkları andan itibaren Batılı Devletlerin himayesinde faaliyetlerini yürüten Pontusçu Rumlar, Birinci Dünya Savaşı'nda ${ }^{16}$ özellikle Fener Rum Patrikhanesi ve metropolitlerin

14 Pontus Meselesi, s. 64; Mesut Çapa, Pontus Meselesi, Trabzon 2001, s. 53-54; Balcıoğlu, a.g.m., s. 92. Misyoner okullarından İstanbul'daki Robert Koleji Bulgar, Suriye Protestan Koleji de Arap milliyetçiliğinin gelişmesinde etkisi olmuştur. Pontusçuluk faaliyetlerinde ise Merzifon Amerikan Koleji aynı görevi üstlenmiştir. Bkz. Gülbadi Alan, "Anadolu'daki Yabancı Okullar ve Pontusçuluk", Başlangıçtan Günümüze Pontus Sorunu, Ed. Veysel Usta, Ankara 2007, s. 182. Merzifon Amerikan Koleji'nde Pontusçuluk faaliyetleri için bkz. Rahmi Çiçek, "Merzifon Amerikan Koleji ve Pontus Sorunu", Başlangıçtan Günümüze Pontus Sorunu, Ed. Veysel Usta, Ankara 2007, s. 207-210; Nuri Yazıcı, Millî Mücadele'de Canik Sancağı'nda Pontusçu Faaliyetler (1918-1922), Ankara 2003, s. 59-63.

${ }^{15}$ Yazıcı, a.g.e., s. 65-68.

16 Sanayileşen devletlerin hammadde ve pazar ihtiyacını gidermek açısından mevcut sömürgelerini korumak ya da genişletmek çok önemli idi. Birinci Dünya Savaşı öncesi, son 50 yıl içerisinde yapılan antlaşmalar savaşın iki blok arasında gerçekleşmesine yol açmıştır. Bir tarafta İngiltere, Fransa ve Rusya'nın olduğu İtilaf Devletleri; diğerinde ise Almanya, Avusturya-Macaristan ve Osmanlı Devleti bulunmaktaydı. İtalya ise nihayet İtilaf bloğunda yer almıştır. Devletler arasındaki anlaşmazlıklar o kadar fazlaydı ki savaşın çıkması bir bahaneye bakmıştır. 28 Haziran 1914 tarihinde Avusturya-Macaristan veliahtı ve eşinin bir Sırplı tarafından öldürülmesi savaşı başlatacak olan gelişme olmuştur. 28 Temmuz'da Avusturya-Macaristan'ın Sırbistan'a savaş açması üzerine devletlerin savaş ilanları peş peşe gelmeye başlamıştır. Almanya 1 Ağustos'ta Rusya'ya ve 3 Ağustos'ta Fransa'ya, 4 Ağustos'ta Ingiltere Almanya'ya savaş ilan etmiştir. 2 Ağustos 1914 tarihinde Almanya'nın Rusya'ya savaş ilan ettiği tarihten bir gün sonra Osmanlı Devleti, Almanya ile ittifak antlaşması imzalamıştır. Bu durum Osmanlı Devleti'nin savaşta aldığı vaziyeti göstermektedir. Sonuçta meydana gelen gelişmeler doğrultusunda 2 Kasım'da Rusya'nın, 5 Kasım'da İngiltere ve Fransa'nın savaş ilanlarına 12 Kasım'da Osmanlı Devleti karşılık vermiştir. Bkz. Yusuf Hikmet Bayur, Türk Inkılâbı Tarihi, Cilt: II/IV, Ankara 1991, s. 558-593; 614-619; Fahir Armaoğlu, 20 Yüzyıl Siyasî Tarihi (1914-1995), Cilt: 1-2, İstanbul (Baskı Yılı Yok), s. 100-110; Enver Ziya Karal,

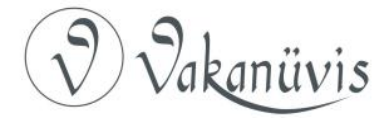


aracılığıyla İtilaf Devletlerinin her türlü maddi ve manevi desteğini almışlardır ${ }^{17}$. Pontusçu Rumların ilk ayaklanmaları Balkan Savaşları sırasında gerçekleşmiştir. Askere gitmeyen ya da askerden kaçan Rumlar, köylerinde veya köylerine yakın yerlerde ikamet ederek buralarda çeteler kurmuşlardır. Balkan Savaşları esnasında Samsun'daki iki Rum köyüne Müslüman muhacirlerin yerleştirilmesi, Rumların Samsun'a saldırmalarına; hatta bir Rum papazın önderliğinde silahlı gücün Samsun'a girmesine neden olmuştur. Bunun üzerine Canik Mutasarrıfının yaptığı uyarılar sırasında Papazın değneğiyle Mutasarrıfın elindeki kitaba vurması, kendilerine olan güveni göstermesi bakımından önemlidir. Zira bu olay, ileride gerçekleştirecekleri isyanların adeta habercisi olmuştur ${ }^{18}$.

\section{Pontusçu Rum Çetelerinin Faaliyetleri}

Birinci Dünya Savaşı́nın başlamasıyla çıkan seferberlik çağrısına uymayan gayrimüslimlerin ${ }^{19}$ içerisinde Osmanlı vatandaşı Rumlar da vardı. Rumların bir kısmı askere gitmedikleri gibi askerlikten muaf olmak için ödemeleri gereken miktarı da vermemişler, ayrıca askere gidenler de belli bir süre sonra firar etmişlerdir ${ }^{20}$.

Yerli Rumların desteğinde Pontus Rum Devleti kurmak amacında olan Rum çetelerinin ${ }^{21}$ yoğun bir şekilde faaliyet gösterdikleri yerlerin başında Orta Karadeniz bölgesi gelmiştir. Çünkü bu bölge, üç yerden

Osmanlı Tarihi, Cilt: IX, Ankara 1999, s. 365-373; 397-399; Rifat Uçarol, Siyasi Tarih (1789-1999), İstanbul 2000, s. 461-469; J. M. Roberts, Avrupa Tarihi, Çev. Fethi Aytuna, İstanbul 2010, s. 599-602; Basil Liddell Hart, Birinci Dünya Savaşı Tarihi, Çev. Kerim Bağrıaçık, Yay. Haz. Edip Gölbaşı-Ülke Evrim Uysal, İstanbul 2014, s. 1-36.

17 Mehmet Okur, "Pontus'çu Faaliyetlerde Batılı Devletlerin Rolü", Osmanlı'dan Günümüze Eşkıyalık ve Terör, Ed. Osman Köse, Samsun 2009, s. 396-397. Ayrıca geniş bilgi için bkz. Çapa, a.g.e., s. 76-93.

18 Balcıoğlu, a.g.m., s. 93. Hatta Balkan Savaşları sırasında Osmanlı vatandaşı Rumların bir kısmı Yunanların yanında savaşmıştır. Bkz. Yerasimos, a.g.e., s. 357.

19 Yerasimos, a.g.e., s. 358.

20 Önder Duman, Emperyal Bir Araç Olarak Rum-Pontus Sorunu (1908-1918), Ankara 2010, s. 45.

21 Justin McCarthy, Ölüm ve Sürgün, Osmanlı Müslümanlarına Karşı Yürütülen Ulus Olarak Temizleme İşlemi 1821-1922, Çev. Bilge Umar, İstanbul 1998, s. 339.

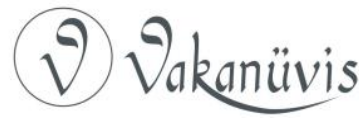


Anadolu'nun iç kısımlarına girilmesine olanak sağlamıştır. Bunlardan biri de Bafra-Kızılırmak deltası-Vezirköprü-Havza-Merzifon güzergâhıdır²2.

Osmanlı Devleti Birinci Dünya Savaşı'na girdikten sonra Pontus Cemiyeti de Samsun, Bafra ve Çarşamba'daki Rum köylerinde sakladığı silahları Rum çetelerine dağıtarak, Rum çetelerinin bölgede faaliyete geçmelerine imkân tanımıştır ${ }^{23}$. Samsun ve çevresindeki Rum çetelerinin özellikle para ve silah malzemeleri Ruslar tarafından tedarik edilmiştir. Hatta çete elebaşlarının maaşlarını dahi Ruslar vermiştir ${ }^{24}$. Rusların Tirebolu'ya kadar ilerlediği bir sırada İngiliz ve Fransız yetkilileri (Sir Mark Sykes ve François Georges-Picot) Osmanlı'nın paylaşıması hususunda yaptıkları anlaşmayı Rus makamlarına sunmuşlardır. Rusya, savaştan önce Samsun-Sivas'ı birbirine bağlayacak demiryolu inşasına göz yummuş olsa da, savaş sırasında Rus işgali altında olan yerlerde Fransızların demiryolu yapımını uygun görmemiştir. Fakat daha sonra Ingiliz, Fransız ve Rusların aralarında vardıkları sınır anlaşmasında "Trabzon'un batısında bir nokta" cümlesine yer verildikten sonra Rus Çarı II. Nikola, ordusu Sinop'a kadar ulaşmayı başarırsa, Rus sınırının buradan başlamasını istemiştir. Bu durumda Ruslar, henüz işgal edilmemiş olan Tirebolu ve Sinop arasındaki toprakları da ele geçirmeyi ${ }^{25}$ ve işgal sürecinde ise Rum çetelerinden faydalanılmasını amaçlamıştır. Bu çetelerin Karadeniz coğrafyasında teşkilatlanmasını Rusya fırsata çevirerek, Rum çetelerini himayesine almışlardır. Böylece Ruslar, Türk askerini hem cephede hem de cephe gerisinde iki ateş arasında bırakarak zayıf düşürmeyi planlamıştır. Trabzon'daki Rus komutan Albay Artatov'un Rum çete elebaşlarıyla 1916 ortalarında Trabzon'da yaptığı görüşmeler sonucunda şu hususlar benimsenmiştir ${ }^{26}$ :

- Rumların Osmanlı birliklerinde askerlik yapmamalarını sağlamak,

22 Diğer güzergahlardan ilki Samsun-Kavak-Havza ile Ladik-Erbaa-Tokat, diğeri de Çarşamba-Yeşilırmak deltası-Erbaa-Tokat-Sivas yoludur. Bkz. Duman, a.g.e., s. 82-83.

23 Pelin İskender Kılıç, "Samsun ve Çevresinde Pontus Çetelerinin Faaliyetleri ve Hükümetin Uygulamaları", Turkish Studies, Vol. 6/2, Spring 2011, s. 489.

${ }^{24}$ Duman, a.g.e., s. 88-89.

25 Yerasimos, a.g.e., s. 359-360.

26 Duman, a.g.e., s. 85-86.

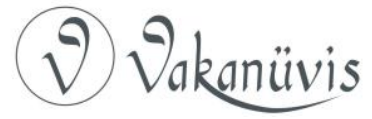


- Osmanlı toprakları içerisinde Rusya'nın düzenli gücünü teşkil etmek,

- Rus ordusunun ileri harekâtı sırasında telgraf ve telefon hatlarını kesmek,

- $\quad$ ilerleyen Rus ordularıyla birlikte girdikleri köy ve kasabalarda Müslümanları katletmek,

- $\quad$ Çete faaliyetlerini sona erdirmek için Hıristiyanların iç bölgelere sevkleri kararlaştırıldığı takdirde isyan edilerek sevke engel olmaktır.

Samsun'a dönen çete üyeleri, Rum halkının çetelere katılımı için burada propagandaya ${ }^{27}$ başladılar. Propaganda faaliyetleri özellikle Bafra'daki Rumlar üzerinde etkisini göstermiştir ${ }^{28}$. Samsun bölgesindeki Pontusçuların başında Samsun Metropoliti Germanous bulunmaktadır ${ }^{29}$. Bafra'da Piskopos Zinan ve Havza'da Piskopos Aristias da Samsun Metropoliti'nin önemli yardımcılarıydı ${ }^{30}$.

Diğer yerlere nazaran Rum nüfus yoğunluğunun fazlalığı, arazinin sarp ve dağlık olması Bafra'nın Nebyan bölgesini Karadeniz'de Pontusçu Rum çetelerinin en önemli faaliyet alanlarından biri olmasını sağlamıştır. Birinci Dünya Savaşı başladığında Nebyan bölgesindeki 17 Rum köyünde 1.457 hanede 8.612 kişi yaşıyordu. Yine 1.500 'e yakın silahlı çete mensubu vardı. Bunlara karşılık 1.000 kadar Türk bulunmaktaydı.

\footnotetext{
27 Propaganda faaliyetleri yurt dışında da sürdürülmüştür. Avrupa'nın değişik yerlerinde yaptıkları konferanslar ile uluslararası alanda etkili olmaya çalışmışlardır. Rusya, Fransa, Ingiltere, Yunanistan ve ABD'nin destekleriyle "Pontus Meselesi"ne uluslararası bir nitelik kazandırılmaya çalışılmıştır. Bkz. Mehmet Okur, "Pontus Meselesinin Ortaya Çıkışı ve Karadeniz Bölgesi'nde Pontusçu Faaliyetleri", Karadeniz Araştırmaları Dergisi (KARAM), Sayı: 14, Yaz 2007, s. 9. 1917 yılında Tiflis'te "Yunanistan Kafkaslar Komitesi", 4 Şubat 1918 'de Giresun eski belediye başkanının oğlu Konstantin Konstantinides Marsilya'da konferanslar düzenlemiştir. Ekim 1917'de Paris'te "Pontus Milli Merkezi" ve $A B D$ 'de "Pontus Komitesi" kurulmuş, ayrıca Atina, Londra ve Atina'da gazete ve dergilerde makaleler yayınlanmıştır. Bkz. Yusuf Sarınay, "Pontus Meselesi ve Yunanistan'ın Politikası", Pontus Meselesi ve Yunanistan'ın Politikası (Makaleler), Yay. Haz. Berna Türkdoğan, Ankara 2006, s. 11-13.

28 Duman, a.g.e., s. 86; Ahmet Tetik, "Çeteler, Venizelos ve Patrikhane", Başlangıçtan Günümüze Pontus Sorunu, Ed. Veysel Usta, Ankara 2007, s. 213.

${ }^{29}$ Goloğlu, a.g.e., s. 241.

${ }^{30}$ Duman, a.g.e., s. 84.
}

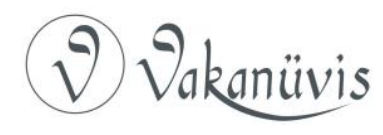


Savaşın başlamasıyla Bafra ve çevresindeki Rumlar, diğer yerlerde olduğu gibi seferberlik emrine uymayıp, çetecilik faaliyetleri için dağlara çekilmiştir. Rum çetelerinin Bafra'daki ilk faaliyeti Kasnakçımermer köyünde gerçekleşmiştir. Burada 2 Türk sırt sırta gelecek şekilde bağlanarak yakılmıştır ${ }^{31}$. Ekim 1917 ortalarında Dimitri, Kara ilya, Piç Vasil, Yaylalı Kel Sava, Deli Andon ve Vasil'in başında bulunduğu 600'e yakın çete üyesinin Bafra'nın Çağşur köyüne yaptığı saldırı sonucunda köydeki bütün evler yakılmış, 38'i kız çocuğu ve kadın olmak üzere 68 kişi öldürülmüştür. Ölen 68 kişiden $15^{\prime}$ i çıkan yangın sonucunda hayatını kaybetmiştir. Çağşur Faciasından sonra geride kalan 498 kişi Bafra'ya sevk edilerek güvenlikleri sağlanmıştır. Bölgeye asker gönderilerek Rum çetelerinin peşine düşülmüş, askeri takipten bunalan çete elebaşları Bafra Kaymakamlığı ve köy muhtarlarına mektup yazarak Çağşur'daki faciadan sorumlu olmadıklarını belirtmiş ve takibin durdurulmasını istemişlerdir. Ayrıca gönderdikleri mektuplarda tehditkâr bir dil kullanmaktan da çekinmemişlerdir ${ }^{32}$. Aslında Pontusçu Rum çeteleri Çağşur Faciasıyla kötü ve acımasız niyetlerini ortaya koymuşlardı ${ }^{33}$. Yine aynı bölgede yer alan Koşaca köyünü de basan Rum çeteleri daha sonra Boyalı, Türkmenler, Kasnakçı, Kuşkayası, Çepniler köylerine saldırmışlardır ${ }^{34}$.

Bafra-Samsun arasında yer alan Engiz köyü civarında faaliyet yürüten Rum çetelerine mensup 3 kişinin Osmanlı askerleriyle girdiği çatışma sonucunda silahlarıyla sağ olarak yakalandığı Harbiye Nezareti tarafından 20 Ocak 1917 tarihli yazıyla Dâhiliyeye bildirilmiştir ${ }^{35} .20$ kişilik bir Rum çetesi, Bafra çevresinde görev yapan Samsun Nokta Komutanlığına bağlı askerlere saldırmış ve askerlerden 1 'ini şehit ettikten sonra sahilden kayıklara binip kaçmışlardır. Bafra'da yaşayan Halis Bey oğlu Ibrahim isminde biri, Rum çeteleri tarafından katledilmiş, katliamda bulunan çetecilere yardım ve yataklık eden 3 Rum tutuklanmıştır. Bunun üzerine Rum çetelerinin gerçekleştirdikleri

\footnotetext{
31 Pontus Meselesi, s. 189.

32 Duman, a.g.e., s. 104, 106-107; Yazıcı, a.g.e., s. 78. Çağşur Faciasında vefat edenlerin listesi için bkz. Duman, a.g.e., s. 105-106.

33 BOA, DH. ŞFR., nr. 00571-00085-001-006; BOA, DH. ŞFR., nr. 00571-00085-001-007.

34 Pontus Meselesi, s. 189.

35 BOA, DH. EUM. 3.şb., nr. 00019-00064-001-001.
}

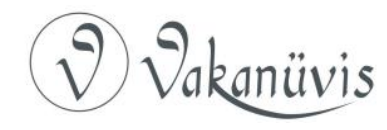


eylemlerle ilgili takibat ve soruşturmaların devam ettiği 30 Temmuz 1917 tarihli yazıda ifade edilmiştir ${ }^{36}$. 5 kişilik bir Rum çetesi, Bafra'ya bağlı Yertib köyünde yaşayan Kadıasker oğlu Ahmet'in eşini yaralayıp mallarını gasp etmiş, 20 kişilik bir başka Rum çetesi de yaraladıkları Arnavut muhacirlerinden Ahmet'in Haru köyüne saldırmışlardır ${ }^{37}$. 1918 'in 15 Mart gecesi Deli Andon'un başında olduğu 20 süvari ve 30 piyadeden oluşan toplam 50 kişilik çete, Bafra'ya bağlı Engiz köyü civarında yer alan Balık gölünde yaşamını sürdüren kayıkçılara saldırarak 9 kişiyi katletmiş, 3'ünü de yaralamıştır ${ }^{38}$. Bafra Savcısı, jandarma komutanı ve belediye doktorundan oluşan heyet, soruşturma yapmak üzere olay yerine gitmiş ve incelemede bulunmuşlardır ${ }^{39}$. Katliam

\footnotetext{
${ }^{36}$ BOA, DH. EUM. 3.şb., nr. 00023-00007-002-001.

37 Kılıç, a.g.m., s. 491.

${ }^{38}$ BOA, DH. EUM. 6. Şb., nr. 00055-00027-002-001; BOA, DH. ŞFR., nr. 00580-0019-001 ve 005 arası.
}

${ }^{39}$ Yapılan inceleme sonucunda katliam şöyle gerçekleşmiştir: Rum çete elebaşı Andon ve 50 kadar adamı saat 20:00 civarında Balık gölü kenarındaki kulübelerde balıkçılık yapan Sürmeneli Osman ile Hüseyin Reis, kardeşleri İsmail, Mustafa Ömer; Oflu Mehmet Ali ve kardeşi Ahmet Ali; Akçaabatlı Çecizoğlu Ali; Değirmencioğlu Muharrem; Samsun'un Hançerli mahallesinden Sarı Mehmet oğlu Mehmet; Reis oğlu Celal; Akçaabatlı İvan oğlu Ömer; Hopalı Tahir Efendi oğlu Şemsettin; Kavaklı Ali ve oğlu Hilmi; Samsunlu Bilal; Kayıkçı Temel; Ahmet; Şükrü; Engiz köyü muhtarının oğlu Şükrü; Samsun Düzköy'den Vasil, Kuzma, Kiregi, Yanko, Paskal, Postbıyık Topal Hacı Şamil; Kızılgöl'den Camus Lazari oğlu Kosti; yine Kızılgöl'den olup isimleri soruşturma sırasında belirlenemeyen 30 kadar kadın; Balık gölünden Balık rüsumu tahsilatıyla görevli Bafra İcra Dairesi'nden Ali Efendi ile hizmetkarı Süleyman ve bu kişileri Bafra'ya getirmek üzere orada bulunan Sürmeli köyünden Arabacı Anayoya isimli kişilerin karşısında yemek yedikten sonra Rumların evlerine gitmelerine izin vermişler. Ardından Hüseyin Reis ve kardeşi İsmail, Oflu Mehmet Ali, Akçaabatı Hançer oğlu Ali, Değirmencioğlu Muharrem, Kavaklı Ali, Samsunlu Sarı Mehmet oğlu Mehmet ve eniştesi Reis oğlu Celal, Akçaabatlı Ömer, Hopalı Şemsettin, vergi tahsildarı Ali Efendi ve hizmetkârı Süleyman ile Engizli Şükrü'yü kulübelerin birinde toplayıp para ve eşyalarını gasp etmişler. Aldıkları parayı yetersiz bulduklarından Deli Andon ve arkadaşları Ayestil, Kuyrak, Kupar ile 1-2 kişi daha ateş ederek 9'unu katletmişler; Celal, Ömer ve Şemsettin'i ağır yaralamışlardır. Katliamdan sonra kulübede bulunan balık, un, tuz gibi yiyecek maddelerini alarak kaçmışlar. Ayrıca kaçarken Bafra-Samsun güzergahındaki karakollar arasında iletişimi sağlayan telgraf direkleri ve tellerine zarar vermişlerdir. Bkz. BOA, DH. EUM. 6. Şb., nr. 00055-00027-003-001.

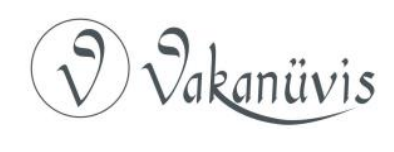


üzerine Dâhiliye Nezareti, Canik mutasarrıflığından Deli Andon ve çetesinin yakalanmasını istemiştir ${ }^{40}$.

10 Mayıs 1918 tarihinde Bafra'nın Muameleli köyü civarında 10 kişilik Rum çetesi ile Yediş Karakolu'nda görevli askerler ve askerleri destekleyen Müslüman köylü arasında meydana gelen çatışma sonucunda çete üyelerinden $1^{\prime}$ i öldürülmüş, 2'si yaralanmıştır ${ }^{41} .27$ Mayıs gecesi Bafra'nın ilyaslı köyüne gelerek iki çift büyük baş hayvanı gasp eden bir Rum çetesiyle girişilen çatışma sonucunda eşkıyadan 3 kişi öldürülmüş, gasp edilen hayvanlar geri alınmıştır'22. 28 Mayıs'ta Bafra'nın bir köyünde, içerisinde kadınların da olduğu 6 kişilik gruba saldıran 20 kişilik bir Rum çetesi, 3 erkeği katletmiş, grubun elindeki zahireleri ve öldürdükleri kişilere ait beygir ve eşeği alarak kaçmışlardır. Daha sonra eşkıya takibi sonucunda gasp edilen hayvanlar geri alınmıştır. Bir gün sonra yani 29 Mayıs'ta Bafra'nın Sarpon köyünde Rum çetelerinin gizlendiği haberinin alınmasıyla köy kuşatılmış, üç saat devam eden çatışma sonucunda 6 çete üyesi öldürülmüş, 2 tüfek ele geçirilmiştir ${ }^{43}$. 8 Haziran'da Bafra'nın Galebe köyünü basan Rum çetesiyle Müslüman köylü arasında meydana gelen çatışma sonucunda Müslümanların 1'i şehit olmuş, 1'i de yaralanmış iken Rum çete üyelerinden 3'ü yaralanmıştır ${ }^{44}$. 17 Haziran'da Bafra merkezde yaşayan Arnavut Bekir adında birisi Şarlan köyüne giderken Rum eşkıyası tarafından katledilmiştir ${ }^{45}$. Bafralı Salim ve Şevket Efendilere ait Kerte köyündeki çiftlik, Rum çetesi tarafından yakılmıştı ${ }^{46}$. Çiftlikte müstahdem Fahri şehit edilmiş, 1 kadın ile 4 çocuğunun akıbeti hakkında bilgi alınamamıştır ${ }^{47}$.

\footnotetext{
DH. ŞFR., nr. 00085-00251-001-001.

41 BOA, DH. EUM. 3. Şb., nr. 00025-00060-001-001.

42 BOA, DH. EUM. 6. Şb., nr. 00038-00038-001-001.

${ }^{43}$ BOA, DH. EUM. 3. Şb., nr. 00025-00072-001-001.

${ }^{44}$ BOA, DH. EUM. 3. Şb., nr. 00025-00071-001-001.

45 BOA, DH. EUM. 3. Şb., nr. 00025-00073-001-001.

46 BOA, DH. EUM. 6. Şb., nr. 00040-00041-001-001.

${ }^{47}$ BOA, DH. EUM. 6. Şb., nr. 00037-00052-001-001.
}

40 BOA, DH. EUM. 6. Şb., nr. 00055-00027-004-001. Yine başka bir şifrede; Deli Andon ve çetesine yönelik takibin arttırılması ve sonucun bildirilmesi istenmektedir. Bkz. BOA,

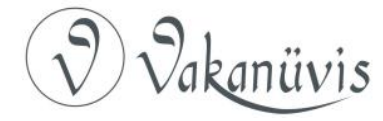


Şimdiye kadar verilen örnekler dışında Canik mutasarrıflığından Dâhiliye Nezaretine gönderilen telgraflarda Pontus Rum çetelerinin gerçekleştirdikleri katliamlara ilişkin toplu bilgiler verilmektedir. 24 Şubat-28 Mart 1918 tarihleri arasında Bafra kazası dahilinde Rum çeteleri tarafından Osmanbeyli'de 1, Düzköy'de 2, ismi okunamayan bir başka köyde 11, Sürmeli köyünde 5, Gazibeyli'de 1, Kıralaca'da 2 hane yakılmış, Çalköy'de 5, Sarmaşık'ta 1 Müslüman katledilmiş ${ }^{48}$, Candar'da 60 hayvan gasp edilmiştir. Bunlara karşlık güvenlik güçlerinin takibi sonucunda 140 çete üyesi öldürülmüş, askerlerden 1'i şehit olmuş, 17'si yaralanmıştır ${ }^{49}$. 4 Mart-23 Mayıs 1918 tarihleri arasında Bafra'daki güvenlik güçleri tarafından gerçekleşen takip sonucunda 219 çete üyesi ölü, 11 'i yaralı ve 4'ü sağ yakalanmıştır. Gasp edilen hayvanlardan 178 büyük baş hayvan geri alınmış ve 55 silah ele geçirilmiştir ${ }^{50}$. Bunlara karşılık Müslüman ahaliden 5 şehit ve 5 yaralı ile takip müfrezesinden 3 asker yaralanmıştı ${ }^{51}$.

23 Nisan 1918 tarihinde Canik mutasarrıflığından Dâhiliye Nezaretine gönderilen bir yazıda; 50'si Ermeni ve diğerleri Rum olmak üzere 420 kişiden oluşan 6 çetenin Bafra'da faaliyet gösterdiği, değişik yerlerden 293 Ermeni'nin Samsun'un bir başka kazası olan Çarşamba'da faal olduğu belirtilmiştir. Merkez sancak ile Terme, Ünye, Fatsa kazalarında çete faaliyetlerinin iki ay öncesine göre katliamlarda bulunmaktan ziyade değirmen basmak, köylünün zahire ve hayvanlarını gasp etmek şeklinde suçlar işlediği ifade edilmiştir. Ayrıca aynı yazıda dikkati çeken hususlardan biri de faaliyetlerin özellikle Bafra'da görülüyor olması ve çete elebaşlarının önemli bir kısmının Bafralı olmasıdır ${ }^{52}$.

Rum çetelerinin bölgede yoğun bir şekilde saldırılar düzenlemeleri Osmanlı yetkililerince raporlar hazırlanmasına neden olmuştur. Karadeniz coğrafyasında Rum çetelerinin faaliyetlerini araştırmak için

\footnotetext{
48 BOA, DH. ŞFR., nr. 00578-0082-001-001; BOA, DH. ŞFR., nr. 00578-0082-001-002.

49 BOA, DH. ŞFR., nr. 00578-0082-001-003 ve 007 arası.

${ }^{50}$ BOA, DH. ŞFR., nr. 00585-00031-001-001.

${ }^{51}$ BOA, DH. EUM. 6. Şb., nr. 00037-00052-001-001.

52 BOA, DH. EUM. 6. Şb., nr. 00040-00015-005. Ayrıca bkz. BOA, DH. ŞFR., nr. 005820073-001-001 ve 004 arası.
}

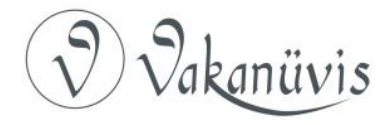


kurulan soruşturma heyetlerinden birinin 23 Ağustos 1916 tarihli raporuna göre; Samsun, Bafra, Çarşamba, Terme, Ünye ve Sinop bölgelerindeki çete elebaşlarının kimlikleri belirlenmiştir. Bunlar içerisinde Bafra bölgesinde faaliyet yürüten çete elebaşlarının isimleri şunlardır: Sava, Deli Andon, Kara İlya, Yuvan ve Tutor (Dikran). Fakat Tutor öldükten sonra çetesi aynı köyden Arsuri tarafından idare edilmiştir ${ }^{53} .1917$ yılına ait raporların birinde Samsun'da 11, Bafra'da 13, Çarşamba'da 8, Terme ve Ünye'de 3 çete vardı. Canik mutasarrıfığına göre ise Bafra'daki çete sayısı aynı olmakla birlikte Samsun ve Çarşamba'da 15, Terme'de 6, Giresun'da 3 ve Ordu'da 1 çete bulunmaktaydı. Bafra'daki 13 çete elebaşının isimleri ve ikametgâhları ise şöyleydi: Bafra'nın Domuzağıl köyünden Sava, Kurugökçe köyünden Deli Andon ve bacanağı Yanika, yine aynı köyden Abanosun Yorgi, Atılgan köyünden Kara İlya, Bafralı köyünden Yuvan ve Yanika, Ladikli köyünden Tutor diğer ismiyle Dikran, Derecik köyünden Sava diğer ismiyle Venizelos, Kızılgök köyünden Yanko, Taflan köyünden Küçük İstil, Ebeşli köyünden Vasil Usta, Kertme köyünden Bayayani oğlu Teofidus ${ }^{54}$.

Her ne kadar önlemler alınıp çete faaliyetleri sona erdirilmek istenmişse de olumsuzluklar yaşanmıyor değildi. 23 Nisan 1918 tarihli Sivas Valisinin Dâhiliye Nezaretine gönderdiği yazı bu anlamda önemlidir. Yazıda; Vali iki noktaya vurgu yapmıştır. Birincisi; çetelerin zulmü, diğeri ise en büyüğünden küçüğüne kadar askeri rütbelilerin kanunlara uymayıp, keyfi davranışlarda bulunmasıdır. Valinin aktardığına göre Amasya sancağında asayiş o kadar bozuktu ki Makedonya'nın 1900'lü yılların başındaki halini andırmakta ${ }^{55}$, köylülerin

\footnotetext{
53 Tetik, a.g.m., s. 211.

54 Duman, a.g.e., s. 93-95. Metinde ifade edilenlerin dışında Bafra kazasına bağlı köylerden olup çete kuranların isimleri için bkz. Duman, a.g.e., s. 96-102.

55 Yüzyıllar boyunca Osmanlı egemenliğinde olan bölgede merkezi otoritenin zayıflamasıyla Yunanistan, Bulgaristan ve Sırbistan arasında bir hâkimiyet mücadelesi görülmeye başlanmıştır. Kurdukları komiteler vasıtasıyla insan kaçırma, soygun, tedhiş faaliyetlerinde bulunarak asayişsizliğin kaynağını oluşturmuşlardır. Ayrıca büyük devletlerin özellikle Rusya ve Avusturya-Macaristan'ın Balkanlardaki rekabeti "Makedonya Sorunu"nun uluslararası bir mesele haline gelmesini sağlamıştır. Rusya ve Avusturya-Macaristan tarafından teklif edilen Mürszteg Programı, İngiltere'nin Makedonya üzerindeki ıslahat projesinin hafifletilmiş hali olup Ekim 1904 tarihinde Osmanlı Devleti tarafından kabul edilmiştir. Fakat Makedonya'da "komitacılık"
}

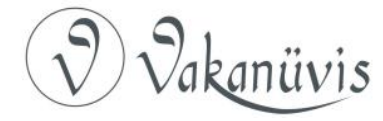


can, mal ve namus güvenliği sağlanamadığı gibi sancak ve kazalar arasındaki yollar da güvenli değildi. Ayrıca bölgede eşkıyalık hareketlerinde bulunanlar öncelikle Rumlar olsa da Müslümanlardan oluşan çeteler de vardı; hatta bazen Rumlar ile Müslümanlar birlikte hareket etmişlerdir. Çetelerin sayısı 20 ilâ 100 arasında değişmekle beraber birleştiklerinde sayı 300'e varmıştır. Bu çetelerin takip edilip ortadan kaldırılması vazifesi Samsun havalisi komutanı Rıza Paşa'nın sorumluluğunda olmasına rağmen bu kişi eşkıya hareketlerini engellemek için zaman harcayacağına tütün satmakla uğraşmıştır ${ }^{56}$.

Bafra merkez ve bağlı köylerinde faaliyet gösteren Pontusçu Rum çeteleri, ayrıca Bafra'nın komşu çevrelerinde de görülmüştür. Deli Andon'un başında bulunduğ $u^{57}$ Rum çetesinin gerçekleştirdiği katliamla ilgili incelemede bulunmak üzere Ekim 1917 tarihinde Sinop'un Boyabat kazasına bağlı aynı zamanda Bafra'ya sınır olan Taşağı köyüne giden Boyabat Savcısı Kamuran ve Sertabibi İrfan Beylerin incelemeleri sonucunda şu tespitlere varılmıştır: Bafra ve Vezirköprü'den gelen Rum çeteleri Taşağıl'a beş dakika mesafedeki Alpoğan köyünü basarak, köyün zenginlerinden Elmacı Ali Ağa'nın büyük oğlu Emin'i kaçırıp karşılığında 300 lira nakit, 200 lira değerinde de altın talep edilmiştir. Ali Ağa bulabildiği 25 lira nakit parayı, köylülerden Onbaşı Bekir isminde biriyle göndermişse de, para eşkıyalar tarafından yetersiz bulunmuş, ayrıca Ali Ağa'nın bizzat gelmesi istenmiştir. Ancak hayatı tehlikeye gireceğinden Ali Ağa teklifi kabul etmemiş, nitekim parayı da tamamlayamadığı için oğlunu Rum çetelerin elinden kurtaramamıştır ${ }^{58}$. Emin, Sılakapulu yaylasında bir kayalıkta öldürülmüş halde çobanlar tarafından bulunmuş ve bu durum askeri yetkililere bildirilmiştir.

\footnotetext{
faaliyetleri yine de devam etmiştir. Dolayısıyla Anadolu'da Ermeniler, Karadeniz'de Rum çetelerinin yaptıklarıyla Makedonya'dakiler arasında fark bulunmamaktadır. Geniş bilgi için bkz. Fahir Armaoğlu, 19. Yüzyıl Siyasî Tarihi (1789-1914), Ankara 2003, s. 580-592; Enver Ziya Karal, Osmanlı Tarihi, Cilt: VIII, Ankara 1995, s. 146-161. Makedonya'da Yunanlar ile Bulgarlar arasında meydana gelen çatışmaların kışkırtıcıları arasında 19001907 yılları arasında Kastoria Metropoliti olan Germanos yer almaktadır. Bu faaliyetlerinden dolayı merkeze alınan Germanos, daha sonra Samsun'a atanarak yıkıcı faaliyetlerine burada da devam etmiştir. Bkz. Küçüker, a.g.e., s. 88.

${ }^{56}$ BOA, DH. EUM. 6. Şb., nr. 00040-00015-0011.

57 BOA, DH. EUM. 6. Şb., nr. 00029-00054-003-001.

${ }^{58}$ BOA, DH. EUM. 6. Şb., nr. 00029-00054-008-001.
}

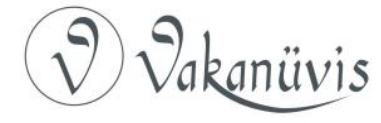


Soruşturma heyetinin raporunda; "Emin'in vücudunda et namına bir şey kalmadığı gibi her bir kemik dere içerisinde bulunup bir araya getirilmiştir ${ }^{59}$." cümlesine yer verilerek katliamın korkunç boyutunu ortaya koymaktadır. Bu korkunç olaydan başka soruşturma neticesinde Rum çetesinin içerisinde doktorların da olduğu belirlenmiştir. Bunların dışında köydeki 100 hayvan, köylüye ait eşyalar Rum çetesince gasp edilmiş, para vermeyenlerin kızları kaçırıımış, hatta kızların ayakları yakılarak işkencede bulunulmuştur. Ayrıca soruşturma sırasında biri Bafra'nın Pelitbükü köyünden Karaosmanoğullarından Hasan oğlu Mustafa ve diğeri Mustafa'nın arkadaşı İbrahim adlarında iki asker kaçağı da yakalanmıştır. Mustafa'nın üzerinden; "Rum çetelerine hitap, merkum Mustafa'ya tesadüf olunduğu takdirde ilişik eylememeleri." yazılı bir kâğıt çıkmıştır. Yine bu şahıs, Rum çetelerinin köyleri yağmalayacağını, yağmalamalar karşısında hükümetin Rum çetelerine karşı bir şey yapamayacağını ve köylülerin yerlerini terk etmeleri gerektiğini belirten propagandalar yapmıştır ${ }^{60}$. Dolayısıyla bu durum Rum çeteleriyle iş birliği içerisinde olan yerlilerin de olduğunu göstermektedir.

Birinci Dünya Savaşı sırasında alınan birtakım tedbirler sayesinde çete faaliyetleri sınırlı bir şekilde gerçekleşmiş olsa da 30 Ekim 1918 tarihinde Mondros Ateşkes Antlaşması'nın imzalanmasından sonra Osmanlı ordusunun terhis edilmesiyle Pontus Rum çetelerinin faaliyetlerini serbest olarak sürdürmelerinde artık hiçbir engel kalmamıştır ${ }^{61}$.

\footnotetext{
${ }^{59}$ BOA, DH. EUM. 6. Şb., nr. 00029-00054-006-001.

60 BOA, DH. EUM. 6. Şb., nr. 00029-00054-008-001.

61 Trakya ve Batı Anadolu'yu işgal eden Yunanların hedefinde Ankara yer almıştır. Yunanistan Başbakanı Venizelos, Doğu Karadeniz' de sayıları 20-25.000 arasında değişen Rum çetelerine, Samsun'dan çıkartma yapacak 6-7.000 kişiden oluşan Yunan ordusuyla Ankara'ya yürümeyi amaçlamıştır. Venizelos, üç hafta içerisinde Ankara'ya ulaşmayı planlamıştır. Planın işlerlik kazanması amacıyla Pontus Rum çetelerinin Orta Karadeniz'in geçitlerinde düzenledikleri saldırılar, aynı zamanda Türklere yönelik katliamlara dönüşmüştür. TBMM hükümetinin Ermenilere karşı kazandığı başarılarla Doğu'nun güvenliği sağlandıktan sonra Pontus Rum çetelerinin üzerine gidilerek, Yunanların bu planı devreye girmesi engellenmiştir. Yunanlar sadece Samsun, Trabzon ve İnebolu'yu bombalamakla yetinmiştir. Bkz. Sarınay, a.g.m., s. 35-40. Milli Mücadele döneminde Rum çetelerinin Bafra ve çevresindeki mezâlimi için bkz. BOA, DH. EUM.
}

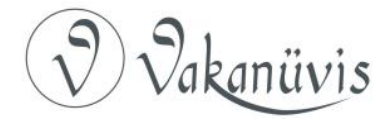




\section{Pontusçu Rum Çetelerinin Faaliyetlerine Karşı Alınan Tedbirler}

Pontus Rum çetelerine karşı güvenliği sağlamakla görevli bulunan jandarma kuvvetlerinin üçte ikisi, 1916 başlarında çıkan düzenlemeyle orduya katılmıştır. Bu durum özellikle çetelerin takibinde önemli bir görev üstlenen süvari jandarma tabur sayısını azaltmıştır. Bu eksiklik, 23 Mart 1916 tarihinde çıkarılan kanunla askerlik görevini yapmayanlarla giderilmeye çalışılmıştır. 20 yaşından büyük ve silah kullanabilen kimseler, maaş karşılı̆ıında jandarmaya alınmıştır. Her türlü eğitimden yoksun ve çoğunlukla 45-50 yaşlarında olan bu güçle Rum çetelerine karşı başarı sağlamak zor olduğundan 19 Haziran 1916 tarihinde çıkan talimatnameyle Takip müfrezeleri kurulmuştur. Bu müfrezeler; Bafra, Çarşamba, Erbaa, Havza, Merzifon ve Niksar bölgelerinde Pontusçu Rum çetelerinin üzerine gönderilmiştir. Alınan bir diğer önlem ise halkın kendilerini korumaları için onlara silah dağıtımı olmuştur. Ayrıca Pontusçu Rum çeteleriyle yapılan çarpışmalar sonucunda hayatını kaybedenlerin ailelerine maaş bağlanmış ya da belli bir miktar para verilmiştir. Alınan bu tedbirler sayesinde Orta Karadeniz bölgesi dışında Rum çetelerine karşı önemli başarılar elde edilmiştir. Orta Karadeniz'de başarı sağlanamamasının en önemli nedeni ise Canik ve Sivas bölgelerinde sivil ve askeri makamlar arasındaki yetki karmaşasından kaynaklanmıştır. Şöyle ki ilk başta çete takiplerinde yetkili makam askeriyede iken 1917'de mülkî makama geçmiş, daha sonra 1918 başlarında yeniden askeriyeye verilmiştir. Böylece çete takiplerinde istikrar sağlanamamış, hatta bu durum makamları birbirlerini suçlayıcı bir hale düşürmüştür. Bunların yanı sıra kullanılan silahların Rum çetelerine göre daha düşük seviyede olması, bazı rütbelilerin askerlik görevi dışında ticaretle uğraşması gibi nedenler, Pontus Rum çetelerine karşı mücadeleyi olumsuz etkilemiştir ${ }^{62}$. Rum çeteleriyle olan mücadelede bazen de Takip müfrezelerinin silahları yetersiz kalmıştır. Hatta müfrezenin elindeki Martin tüfekleri pek işe yaramadığı gibi

AYŞ, nr. 00003-00050-001-002; BOA, DH. EUM. 3. Şb., nr. 00027-00060-001-001; BOA, DH. ŞFR., nr. 00627-0014-001-001; BOA, DH. ŞFR., nr. 00627-0014-001-002; BOA, DH. ŞFR., nr. 00639-0123-001-001; BOA, DH. ŞFR., nr. 00639-0123-001-002.

62 Duman, a.g.e., s. 135-142.

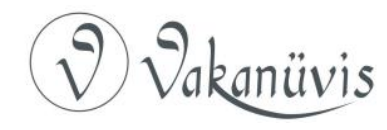


müfrezelerdeki asker sayısı da, Rum çetelerine göre daha az olabiliyordu. Doğal olarak bu durum Müslüman halkın varlığını tehlikeye sokmuştur ${ }^{63}$.

Canik sancağındaki çetelerin takip edilmesinde kalıcı bir başarının elde edilememesi üzerine askeri yetkililerin nitelikli kimselerden seçilmesi gerektiği Canik mutasarrıflığının Dâhiliye Nezaretine çekmiş olduğu 4 Eylül 1918 tarihli şifrede belirtilmiştir. Bu amaçla Bafra, Çarşamba ve Ünye'deki jandarma komutanlarının becerikli ve dürüst kimselerden seçilmesi istenmiştir ${ }^{64}$. Sivas vilayetinden Dâhiliye Nezaretine gönderilen 1 Mayıs 1918 tarihli yazıya göre de çete faaliyetlerine karşı alınacak tedbirlerden biri de vilayet jandarma alayının seferberlikten önceki durumuna getirmekti. Yani genç ve eğitimli askerlerden oluşmasını sağlamaktı. Hâlbuki jandarmaların şimdiki hali bu duruma pek uymuyordu. Her ne kadar asker çok gözükse de bunların çoğu eşkıya takibini gerçekleştirecek eğitimden yoksundu. Daha çok geri hizmet işleri görür vaziyette idi. Eğer belirtilen durum düzeltilmezse vilayet içerisindeki Rum çetelerinin Müslümanları katletmesi kaçınılmazdı ${ }^{65}$.

Bafra Belediye Başkanı Dursun ve eşinin imzalarını içeren 29 Mayıs 1918 tarihli telgraf, çetecilik faaliyetlerinin engellenmesi için ne gerekiyorsa yapılması hakkındaydı ${ }^{66}$. Yine Bafra'da müftülük görevinde bulunan Ahmet Galip ve eşi tarafından Sadarete gönderilen bir dilekçede, Rum çetelerine karşı niçin yeterli karşılığın verilmediği sorulmuştur ${ }^{67}$.

Çetecilik faaliyetleri, Osmanlı Devleti'ni ekonomik yönden de etkilemiştir. Samsun ve havalisinde güvenliği sağlamakla görevli takip müfrezeleri, çete faaliyetlerini durduramadığı için Amasya sancağında toplanması gereken öşür vergisini köylüler verememiştir. Dolayısıyla 20 Haziran 1918 tarihli yazıyla Sivas Valiliği Dâhiliye Nezaretini uyarmıştır ${ }^{68}$.

\footnotetext{
63 BOA, DH. EUM. 6. Şb., nr. 00029-00054-007-001.

${ }^{64}$ BOA, DH. ŞFR., nr. 00594-0090-001; BOA, DH. ŞFR., nr. 00594-0090-003.

65 BOA, DH. EUM. 6. Şb., nr. 00040-00015-013.

66 BOA, DH. EUM. 6. Şb., nr. 00040-00041-003-002.

67 BOA, DH. EUM. 6. Şb., nr. 00040-00041-001-002.

68 BOA, DH. EUM. 6. Şb., nr. 00040-00015-007.
}

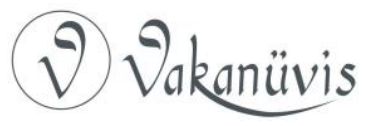


Rumlar, Pontus Devleti kurmak amacıyla bir taraftan çeteler vasıtasıyla her türlü mezâlimi gerçekleştirirken diğer taraftan Ruslar adına casusluk faaliyetlerinde bulunmuşlardır. Bu nedenle Rum kayıkçılar hakkında soruşturma açılmış, denizlerde seyahat yapmaları yasaklanmıştır. Giresun ve Ordu'daki Rumlara güvenilmediğinden askeri yiyecek nakliyatı Türklere verilmiştir. Fakat alınan önlemler yetersiz kalınca Rumlar sevke tabi tutulmuştur ${ }^{69}$. Trakya, Marmara, Batı Anadolu, Antalya ve çevresindeki Rumlar ile Karadeniz sahillerindeki Rumların bir kısmı sevk edilmiştir ${ }^{70}$. Dâhiliye Nezareti'nin Sadaret'e 26 Mayıs 1915 tarihinde gönderdiği tezkire üzerine 27 Mayıs'ta "Vakt-i seferde icraat-ı hükümete karşı gelenler için cihet-i askeriyece ittihaz olunacak tedabir hakkında kanun-ı muvakkat" çıkarılmış ve bu kanun 1 Haziran'da Takvim-i Vekayi' de yayınlanmıştır. Yürürlüğe giren bu geçici kanuna göre sevk ve iskân işlemi gerçekleşmiştir. Bu kanunun ilk maddesinde; savaş sırasında askeri yetkililerin hükümet emirlerine karşı gelenleri ya da asayişsizlik çıkaranlara karşı gerekli önlemleri almaları gerektiği belirtilmiş, ikinci maddesinde de yine askeri makamlarca gerekli görülürse casusluk faaliyetlerinde ya da ihanet içerisinde bulunanların tek olarak ya da toplu halde başka yerlere sevk ve iskân edileceğine yer verilmiştir. Diğer iki madde de ise, kanunun yayınlandığı tarihten itibaren yürürlüğe gireceği ve kanunların uygulanmasından Başkomutanvekili ve Harbiye Nazırının yetkili olduğu ifade edilmiştir ${ }^{71}$.

Kanun maddelerine bakıldığında hiçbir topluluğun ismi geçmemesine rağmen sadece Ermeniler için çıkarılmış bir kanun olduğunu söylemek yanlıştır. Zira Rusların doğuda, İngiliz ve Fransızların batıda saldırıya geçtiği bir sırada casusluk ve çete faaliyetleriyle ülkede huzur ve güvenliği bozan unsurlara karşı Osmanlı hükümeti kayıtsız

\footnotetext{
${ }^{69}$ Balcıoğlu, a.g.m., s. 94.

70 Duman, a.g.e., s. 143.

71 Takvim-i Vekayi, nr. 2189, 19 Mayıs 1331, s. 1; Yusuf Hikmet Bayur, Türk Inkılâbı Tarihi, Cilt: III/ III, Ankara 1991, s. 40; Yusuf Halaçoğlu, Ermeni Tehciri, İstanbul 2007, s. 71; Cemal Sezer, Ermenilerin Sevk ve Iskânı Hakkında Yapılan Uygulama ve Yardımlar (19151917), Selçuk Üniversitesi Sosyal Bilimler Enstitüsü (Yayınlanmamış Doktora Tezi), Konya 2011, s. 24-25. Dâhiliye Nezareti'nin Sadarete gönderdiği tezkire 30 Mayıs 1915 tarihinde Meclis-i Vükelâ'da kabul edilmiştir. Bkz. Bayur, Türk Inkılâbı Tarihi, Cilt: III/ III, s. 37-38.
}

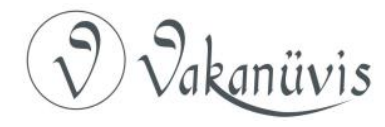


kalmamıştır. Dolayısıyla Ermeniler dışında Rumlar da belirtilen kanuna göre sevk ve iskân edilmiştir ${ }^{72}$.

Pontusçu faaliyetlerinden dolayı Karadeniz'den ilk sevk, 16 Kasım 1916 tarihinde Tirebolu'dan başlamıştır. Buradaki Rumlar, Giresun ve Şebinkarahisar'a sevk edilmiştir. Daha sonra Samsun ile devam eden sevk işlemi, Kadıköy'den 4.000 kişiyle Havza'dan Çorum'a gerçekleşmiştir ${ }^{73}$. Bafra'dan sevk edilen Rumlar da Çorum ve Ankara'ya gönderilmiştir ${ }^{74}$. Ayrıca Bolu ${ }^{75}$ ve Çankırı taraflarına sevk edilenler de olmuştur. Kastamonu vilayetinden Dâhiliye Nezaretine gönderilen 12 Mayıs 1917 tarihli şifrede, Bafra'dan Çankırı sancağına bağlı Çerkeş kazasına bugün 100'e yakın Rum'un geldiği ve burada daha iskân edilecek yerin olmadığı bildirilmekteydi ${ }^{76} .1917$ Ocak sonunda Bafra ve çevresinden, Şubat'ta ise Çarşamba ve Ünye'den yaklaşık 30.000 Rum Ankara vilayetine sevk edilmiştir. Daha sonra Ordu ve Sinop'takiler gönderilmiştir ${ }^{77}$.

Rumların güvenli bir şekilde sevk edilmeleri amacıyla kalabalık teşkil edecek sayıda toplu bulunmalarına izin verilmemiştir ${ }^{78}$. Harbiye Nazırı Enver Paşa, gerekli önlemlerin alınmasını yerel makamlara bildirmiştir. 9 Mart 1916 tarihli Trabzon Valiliğinin yazısı bu doğrultuda olmuştur. Yazı; sevkiyat sırasında olumsuzlukların çıkmaması ve sevkiyatın iş bilir askeri görevliler tarafından yapılmasını içeriyordu. Sevke tabi tutulmak istemeyen Rumlar ise, Canik ve Giresun'da başarısızlıkla sonuçlanacak isyan girişimlerinde bulunmuşlardır ${ }^{79}$.

Birleşen Rum çetelerinin büyük kitleler halinde saldırılarını arttırması üzerine III. Ordu Komutanı Vehip Paşa, Bafra kazasında bulunan Rumların istinasız olarak sevk edilmelerini 28 Ekim 1917 tarihli şifreli telgrafla Canik mutasarrıflığından istemiştir ${ }^{80}$. Böylece Bafra'da ikinci

\footnotetext{
72 Duman, a.g.e., s. 143-144.

73 Yerasimos, a.g.e., s. 362-363.

74 BOA, DH. ŞFR., nr. 00082-00039-001-001.

75 BOA, DH. ŞFR., nr. 00088-00121-001-001.

76 BOA, DH. ŞFR., nr. 00554-00002-001-001.

77 Yerasimos, a.g.e., s. 363-364.

78 BOA, DH. ŞFR., nr. 00076-00243-001-001.

79 Balcıoğlu, a.g.m., s. 95.

80 BOA, DH. ŞFR., nr. 00571-00085-001-004.
}

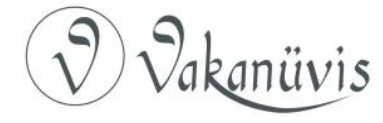


kez sevk işlemi başlamıştır. 17 Kasım'da Canik mutasarrıflığından Dâhiliyeye gönderilen şifrede ise gerçekleştirilecek sevkle sancakta asayişin sağlanamayacağı, geçen yıl sancakta yapılan sevkin çete faaliyetlerini arttırdığı ve Vehip Paşa ile bu meselenin yeniden mutasarrıflıkça görüşüleceği aktarılıyordu ${ }^{81}$. Daha sevkin başında kafilelere saldırı düzenleyen 19 Müslümanın gasp ettikleri eşyalarla yakalanması, Mutasarrıf tarafından örnek olarak verilmiş ve sevke tabi tutulacak Rumların sayısı 20.000 olarak tahmin edilmiştir ${ }^{82}$. Anlaşılıyor ki Vehip Paşa ile Canik Mutasarrıfı arasında sevk işlemi hususunda anlaşmazlık çıkmıştır. Askeri taraf güvenlik anlayışından dolayı sevki zorunlu görüyor, yerel makamlar ise bunun bir işe yaramayacağını tam tersine çete saldırılarının artarak devam edeceğini düşünmüşlerdir.

Bafra kazasındaki Rumların sevk işleminin şu şekilde gerçekleşeceği planlanmıştır: Sevkin uygulanması sırasında Bafra 18 mıntıkaya ayrılacaktı. Sevk belli yerlerde toplanan kafilelerin can, mal, namus güvenliklerini korumak için jandarmalar eşliğinde ${ }^{83}$ olacaktı ve sevk edilenler yanlarına istedikleri eşyaları alabileceklerdi. Alınamayacak eşyalar olursa da yerel makamlar tarafından korumaya alınacaklardı. Belirlenen süre içerisinde kafilelere katılacak, aksi bir durumda zorla katılımlar sağlanacaktı. Kaçacak ya da karşı gelinir ise sert tedbirler uygulamaya konulacaktı. Bafra Kaymakamı tarafından bir beyanname ilan edilip hükümet emirleri yayınlanacaktı. Bir beyanname de Müslümanlar için yayınlanarak, sevk işleminin güvenlikten kaynaklanan bir zorunluluktan doğduğu ve Rumların can, mal ve namus güvenliliklerinin hükümetin koruması altında olduğu belirtilecekti. Eşkıya saldıılarına karşı Müslüman ve sevk dışında kalan Rum köylerinin güvenliği için yeterli sayıda asker verilecekti. Sevk edilecek Rumlar, 500 kişilik kafileler halinde Samsun-Kavak (Çorum, Ankara taraflarına) yoluyla jandarma müfrezeleri eşliğinde sevk edilecekti. Kafilelerden bir jandarma subayı sorumlu olacak, kafileler yolda belirlenecek konaklama yerlerinde kalacak ve iaşeleri Menzil Müfettişliği tarafından karşılanacaktı. Boşaltılacak olan köylerdeki emvâl, eşkıyadan olmamak koşuluyla güvenilir iki Rum tarafından imzalanarak deftere

\footnotetext{
${ }^{81}$ BOA, DH. ŞFR., nr. 00571-00085-001-002.

82 BOA, DH. ŞFR., nr. 00571-00085-001-001; BOA, DH. ŞFR., nr. 00571-00085-001-002.

83 Bu bilgi için ayrıca bkz. BOA, DH. ŞFR., nr. 00571-00085-001-007.
}

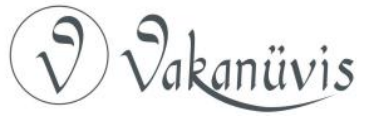


kaydedilecekti. Fakat bölge halkının tamamı sevk edilirse o zaman kaza kaymakamı ve jandarma alay komutanvekilinin ortak sorumluluğu altında emvâl toplanarak güvenli bir şekilde merkez kazaya nakledilecekti. Hayvanlar da güvenilir kişilere teslim edilerek bakımları sağlanacak ve telef olmaları önlenecekti. Bundan başka mevcut zahirelerden istedikleri kadarını yanlarına alabileceklerdi, fakat alamadıklarının çeşit ve miktarı mazbatalara yazılarak korumaya alınacak ve mazbataların bir nüshası sahiplerine verilecekti. Henüz tarlada olan mısırlara ise dokunulmayacaktı. Mısır tarlaları daha sonra belirlenen oranda, köyde iskân edilmiş muhacirlere verilerek toplattırılacaktı. Bunun için ayrıca talimat verilecekti. Sahipleri tarafından toplanıp, henüz kurumamış olan mısırların bozulmalarına izin verilmeyecek; kaza kaymakamı, mıntıka komutanı ve mal müdüründen oluşan komisyon tarafından tutulacak bir raporla kayıt altına alınacaktı. Bozulabilecek her türlü emvâl yerel makamlar tarafından açık arttırma usulü ile satışa çıkarılacaktı. Ama bütün memurlar, rütbeli ve rütbesiz askerler açık arttırmaya katılamayacaktı. Aksi bir durumda derhal işten el çektirilecekti. Tütün satımı ancak çok katılımlı ve hak ettiği değerden olursa satış işlemi gerçekleşecekti. Sevk ve iskân işlemi medeni ve hukuk kurallarına uygun olarak yapılacak ve bundan hiç kimsenin menfaat temin etmesine izin verilmeyecekti. Bafra Kaymakamı Hakkı ve Canik Jandarma Alay Komutanvekili Zebur Beyler, sevk işleminin gerçekleşmesinden ve sevk sırasında olumsuz hareketleri önlemek için gerekli tedbirleri almak ile sorumlu olacaklard ${ }^{84}$.

Bafra'da Rumlar sevk edilmeden önce onlara 10 günlük hazırlanma süresi verilmiştir ${ }^{85}$. Hareket edemeyecek durumda olanlar, hamile kadınlar, hasta ve sakat kimseler ile askerlik vazifesi gören Rumların aileleri sevkten muaf tutulmuş ve yerel makamlarca uygun görülen yerlerde iskânları sağlanmıştır ${ }^{86}$. Sevk, 22 Aralık 1917 tarihinde kaymakamlık vasıtasıyla halka duyurulmuş ${ }^{87}$ ve sevkiyatın yapılması için İstanbul'dan 500.000 kuruş gönderilmiştir ${ }^{88}$.

\footnotetext{
${ }^{84}$ BOA, DH. ŞFR., nr. 00571-00085-001-008 ve 024 arası.

85 BOA, DH. ŞFR., nr. 00572-00078-001-001.

${ }^{86}$ BOA, DH. ŞFR., nr. 00574-00118-001-001 ve 003 arası.

87 BOA, DH. ŞFR., nr. 00574-00118-001-004.

88 BOA, DH. ŞFR., nr. 00574-00085-001-001.
}

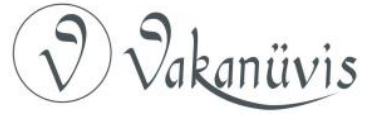


Pontusçu Rum çeteleri, sevk ve iskân kararını olumsuz karşılamışlar ve tepkilerini hem Müslümanlar hem de Rumlar nezdinde göstermişlerdir. Rum çeteleri eğer Müslümanlar sevki engellemek için yerel makamlara müracaat etmezlerse katliama uğrayacaklarına dair tehditler içeren beyanname hazırlamışlardır. Sevke hazırlanan Köseli köyü Rumlarından biri, mallarını kaydetmek üzere merkeze giderken Rum çeteleri tarafından katledilmiştir. Ayrıca Rum çeteleri, Rumların sevk emirlerine uymamalarını, zahire ve eşyalarını teslim etmemelerini ve çetelere katılmalarını istemişlerdir. Bunun üzerine bazı Rumlar, alabildiği kadar yiyecek, giyecek ve diğer eşyalarla Rum çetelerine katılmış, bazıları ise sevke tabi olmak üzere Bafra merkeze gitmişlerdir ${ }^{89}$.

Rumların sevk işlemi, askeri ve mülki amirlerin sorumluluğunda gerçekleşmiştir ${ }^{90}$. Dâhiliye Nezareti'nin bünyesinde yer alan İskân-ı Aşair ve Muhacirin Müdüriyeti vasıtasıyla sevk ve iskân gerçekleşmiştir. Rum sevkiyatı sırasında güvenliklerinin sağlanması için jandarmalar görevlendirilmiştir. Ayrıca kafilelere saldıranların şiddetle cezalandırılmasını Dâhiliye Nezareti vilayet ve mutasarrıflıklardan istemiştir ${ }^{91}$.

Sevk edilen Rumların günlük zaruri ihtiyaçlarını gidermeleri amacıyla yevmiyeler verilmiştir ${ }^{92}$. Örneğin Temmuz 1917 tarihinde belirlenen miktara göre büyüklere 3 kuruş, küçüklere 60 para verilecekti ${ }^{93}$. Ayrıca sevk ve iskân bölgelerindeki vilayet ve mutasarrıflıklara masraflar için İstanbul'dan farklı miktarda paralar gönderilmiştir ${ }^{94}$. Bafra'dan Bolu'ya

89 BOA, DH. ŞFR., nr. 00574-00118-001-004 ve 007 arası. Bafra'nın Kovanlık ve çevresindeki köylerde yaşayan Rumlar, aileleriyle birlikte köylerini terk ederek Rum çetelerine katılmış, Kolay köyündeki Türkler de Rum çeteleri tarafından tehdit edilmişlerdir. Bkz. BOA, DH. ŞFR., nr. 00571-0085-001-004; BOA, DH. ŞFR., nr. 005710085-001-006.

90 Mustafa Özdemir, “I. Dünya Savaşı Sırasındaki Osmanlı Devleti Tarafından Gerçekleştirilen Rum Tehciri”, Çağdaş Türkiye Tarihi Araştırmaları Dergisi (ÇTTAD), Cilt: $\mathrm{VI} / 14$, İzmir Bahar 2007, s. 30-31.

91 Duman, a.g.e., s. 149; Özdemir, a.g.m., s. 32.

92 BOA, DH. ŞFR., nr. 00555-00067-001-001.

93 Osmanlı Belgelerinde Ermenilerin Sevk ve İskânı (1878-1920), Ankara 2007, s. 388389; Duman, a.g.e., s. 149.

94 Duman, a.g.e., s. 149. Ermeni, Rum, Arap ve mülteci durumundaki Müslümanlar için 22 Mart 1917 tarihinde vilayet ve mutasarrıflıklara toplam 6.640 .000 kuruş

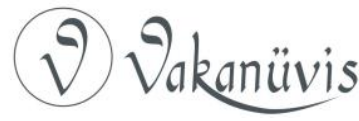


sevk edilen 210 Rum ailesi için Harbiye Tahsisatı'ndan 1.000 lira havale edildiğini Bolu'dan Dâhiliye Nezaretine çekilen 6 Haziran 1917 tarihli şifrede belirtilmiştir ${ }^{95}$. Bafra ve Giresun'dan sevk edilen Rumların iaşe masrafları için Haziran 1918 tarihinde Seferberlik Tahsisatı'ndan 50.000 kuruş gönderilmiştir ${ }^{96}$.

Sevk ve iskân sırasında sorunlar da ortaya çıkmıştır. Bu sorunların başında ise savaş ortamında doğaldır ki görülen nakit sıkıntısıdır. 25 Eylül 1917 tarihinde Bolu mutasarrıflığından Dâhiliyeye gönderilen şifrede; Bafra'dan sevk edilen Rumların gelecek haftadan itibaren iaşelerini sağlayacak paranın kalmadığı, üç aydır Birinci Kolordu Ahz-ı Asker Heyeti ile gerçekleştirilen yazışmalardan sonuç alınamadığından ekim ayının başından itibaren yevmiyelerin verilemeyeceği belirtilmiştir ${ }^{97}$. Diğer bir sorun ise salgın hastalıkların görülmesiydi. Bolu'ya sevk edilen Rumlar arasında tifo hastalığına yakalananlar bulunmaktaydı. Bunların mağdur olmaması ve tedavilerinin sağlanması için gerekli olan para Mülteciler Tahsisatı'ndan karşılanmıştır ${ }^{98}$.

Sevk edilen Rumların geride bıraktıkları malların korunması ya da gerekirse işletilmesi için vilayet merkezlerinde "Emvâl-i Metrûke Komisyonu" adıyla komisyonlar kurulmuştur ${ }^{99}$. Gayrimenkul dışındaki her türlü eşya depolara taşınmıştır. Zamanla zarar görebilecek olanlar varsa, bunlar da bedeli karşılığında açık arttırma usulüyle satılarak, geliri sahipleri adına mal sandıklarına verilmiştir. Eğer satışlarda suiistimal olduğu anlaşıldıysa satışlar iptal edilmiş, görevli memurlar hakkında hukuki süreç başlatılmıştır ${ }^{100}$.

Birinci Dünya Savaşı boyunca 213.483 Rum sevk edilmiş, bunların 62.000'i Canik bölgesinden olmuştur. Bafra'dan sevk edilen Rum sayısını

\footnotetext{
gönderilmiştir. Bu miktarın 80.000 kuruşu Canik mutasarrıfığına ayrılmıştır. Bkz. Özdemir, a.g.m., s. 34-35; Sezer, a.g.t., s. 54. 8 Ekim 1917 tarihinde Canik mutasarrıflığına 1.000 lira olmak üzere vilayet ve mutasarrıflıklara toplam 96.750 lira havale edilmiştir. Bkz. Sezer, a.g.t., s. 55-56.

95 BOA, DH. ŞFR., nr. 00556-00047-001-001.

96 BOA, DH. ŞFR., nr. 00088-00121-001-001.

97 BOA, DH. ŞFR., nr. 00567-00021-001-001.

98 BOA, DH. ŞFR., nr. 00555-00067-001-001.

99 Özdemir, a.g.m., s. 31-32.

100 Duman, a.g.e., s. 150-153.
}

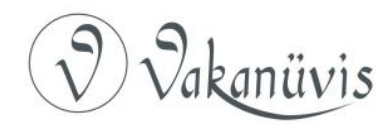


tam olarak vermek mümkün değilse de 20.000 civarında olduğu tahmin edilmektedir. Bu durumda Canik sancağından sevk edilen Rumların üçte biri Bafra kazasından gerçekleşmiştir ${ }^{101}$. Sevk edilen Rumlar, 1918 yılından itibaren geri dönmeye başlamıştır ${ }^{102}$.

Pontusçu Rum çetelerinin Bafra ve çevresindeki faaliyetlerinden dolayı Ekim 1914'ten 1920 yılının sonuna kadar resmi makamlarca adli kayıtlara geçirilen soruşturma sayısı 110'dur. Fakat kayıtlara geçmemiş olanların da bulunduğu varsayılırsa sayının artacağı kesindir. Jandarma ve askeri kuvvetlerin gerçekleştirdikleri soruşturma sayısı ise $83^{\prime}$ tür. 1920 'nin sonuna kadar sadece soruşturmalar sonucunda belirlenenlere göre 534 Türk katledilmiştir. Dolayısıyla belirlenemeyenler eklendiğinde Bafra ve çevresinde katledilenlerin sayısı 600'den fazladır ${ }^{103}$.

\section{Sonuç}

Birinci Dünya Savaşı́nın başlamasıyla Rumların bir kısmı çetecilik faaliyetleriyle Osmanlı Devleti'ni zor durumda bırakarak İtilaf Devletlerine yardımcı olmayı amaçlamıştır. Karadeniz bölgesinde Pontus Rum çetelerinin yoğun olarak faaliyet gösterdikleri yerlerin başında Canik sancağı gelmektedir. Zira diğer yerlere nazaran burada ciddi bir Rum nüfus yoğunluğu vardı ve hedeflenen Rum devletinin merkezi Samsun olacağından önemi büyüktü. Ayrıca liman kenti olması bakımdan gelişmiş bir şehir olan Canik, aynı zamanda iç kısımlarla bağlantıyı sağlayan geçiş yollarına da sahip olup, ayrıca Rusların işgal etmeyi düşündüğü yerlerden biriydi. Dolayısıyla Pontus Rum çetelerinin himaye edilmesinde ve özellikle para ve silah yardımlarının yapılmasında Rusya'nın ciddi boyutta desteği söz konusudur.

Bafra ve çevresi, Rum çetelerinin sancaktaki faaliyet alanları içerisinde önemli bir yere sahiptir. Dağlık ve ormanlık alanlarla kaplı olması ve Türklere göre Rum nüfusunun fazla olmasından dolayı Nebyan dağları Rum çetelerinin merkez karargâhı durumundaydı. Buradaki

101 BOA, DH. ŞFR., nr. 00571-00085-001-001; Arşiv Belgeleriyle Ermeni Faaliyetleri 19141918, Cilt: I, 643.

102 Yerasimos, a.g.e., s. 365. Dâhiliye Nezareti'nden vilayet ve mutasarrıflıklara gönderilen 23 Ekim 1918 tarihli şifre, sevk edilenlerin memleketlerine güvenli bir şekilde dönmeleri için gerekli tedbirlerin alınmasını içermektedir. Bkz. Osmanlı Belgelerinde Ermenilerin Sevk ve iskânı (1878-1920), s. 397-398.

103 Pontus Meselesi, s. 191; Yazıcı, a.g.e., s. 78-79.

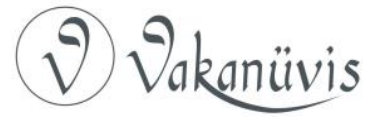


Türklere yönelik Pontusçu eylemler; öldürme, yaralama, tecavüz, kaçırma, fidye isteme, gasp olarak sıralanabilir. Gerçekleştirdikleri katliamlarla Müslüman halkı korkutarak bölgeden göç etmelerini sağlayarak Rum nüfusun çoğunluğu sağlanması amaçlanmıştır. Böylece kurulacak bir Pontus Rum devletinin önündeki en önemli engel kaldırımış olacaktır.

Zalim ve acımasız Pontusçu Rum çetelerine karşı Osmanlı yönetimi, Türkleri katliamdan korumak için birtakım tedbirler almak zorunda kalmıştır. Hatta bazen devlet ile halk dayanışma içerisinde hareket ederek, Rum çetelerine karşı birlikte mücadele etmişlerdir. Alınan tedbirler arasında Bafra'daki Rumların bir kısmının Ankara, Çorum, Bolu ve Çankırı taraflarına sevk edilmeleri vardı. Tamamen güvenlik nedenlerinden dolayı çıkarılan sevk ve iskân kararı, ilk olarak Kasım 1916 tarihinde uygulanmıştır. Ancak çeteler durdurulamayınca ve Rum halkının çetelere olan destekleri devam edince, III. Ordu Komutanı Vehip Paşa yeniden bir sevkiyatın yapılmasını Canik mutasarrıflığından 1917 Ekim sonunda talep etmiştir. Mutasarrıflık, sevkin gereksiz olduğunu ve çete faaliyetlerini sona erdirmeyeceğini Vehip Paşa'ya bildirmiş ve aralarında anlaşmazlık çıkmasına rağmen, Rum sevki gerçekleşmiştir. Fakat Rum çeteleri, sevki engellemek için tehdit edici ifadelerle Rumları uyarmış, uyarılarını dinlemeyenleri öldürmekten çekinmemişlerdir. Türkleri de tehdit ederek, sevki durdurmaları için eylem yapmalarını istemişlerdir. Netice de sevk ve iskân işlemi devletin gücü nispetinde savaşın getirdiği zorlukları da içinde barındırmasına rağmen gerçekleşmiştir. Sevk edilen Rumların güvenli bir şekilde belirlenen yerlere gitmesi için devlet, tüm imkânlarını sonuna kadar kullanmıştır.

Rus Albayın Rum çete elebaşlarıyla gerçekleştirdiği görüşme sonucunda alınan karar gereği; eğer Osmanlı hükümeti sevk kararı alır ise buna uyulmayacak ve birlikte karşı konulacaktı. Bu görüşme sırasında Ermenilerin ve batıdaki Rumların bir kısmı sevk edilmişti. Burada dikkati çeken husus Rum çetelerinin Karadeniz'deki Rumlar için aynı akıbeti beklemeleriydi. Bu doğrultuda Osmanlı yetkililerinin aldığı sevk kararının ne kadar yerinde olduğu ortaya çıkmaktadır. Çünkü Rumların bölgeden çıkarılmasıyla her türlü destekten yoksun kalınacağı ve

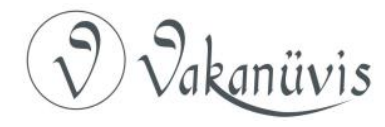


faaliyetlerinin derinden etkileneceğini Pontusçu çete elebaşları çok iyi biliyorlardı.

Birinci Dünya Savaşı'nda Bafra ve çevresindeki Pontusçu Rum çetelerinin faaliyetleri, Osmanlı Devleti'ni ister istemez zor durumda bırakmıştır. Devlet bir yandan cephelerin ihtiyaçlarını karşılarken diğer yandan da cephe gerisini düşünmek zorunda kalmıştır. Öyle ki Birinci Dünya Savaşı yıllarında hiçbir devlet, Osmanlı kadar cephe gerisinde mücadele etmemiştir. Tam da bu noktada şu soruyu sormak gerekir: Savaşın kaybedilmesinde cephe gerisinde Pontusçu Rumların faaliyetlerinin ne ölçüde rolü vardır? Bafra, belki küçük bir bölge olabilir ama Karadeniz'in diğer yerlerini de kapsadığında üzerinde düşünülmeye değer gözükmektedir.

Osmanlı Devleti'nin Mondros Ateşkes Antlaşmasıyla savaştan yenik ayrılmasının ardından Pontusçulara gün doğmuşsa da Karadeniz'deki Türk halkı, tüm varlığı ile bu bölücü harekete karşı olağanüstü bir mücadele vermiştir. Birinci Dünya Savaşı'nda Türklere yönelik başlayan ayrılıkçı Pontusçu hareket, Milli Mücadelenin kazanılmasıyla Anadolu topraklarında son bulmuştur. Fakat günümüzde Yunanistan, Batılı Devletlerin de desteğiyle sözde "Pontus Soykırımını Anma Günü" gerçekleştirerek Pontusçu propaganda faaliyetlerine devam etmektedir. Hatta Mustafa Kemal Paşa'nın (ATATÜRK) Samsun'a çıkıp Milli Mücadeleyi başlattığı tarih olan 19 Mayıs 1919 tarihine atfen, sözde soykırım tarihini "19 Mayıs" olarak belirlemeleri manidardır ve Milli Mücadeleye olan menfi bakışlarını ortaya koymaktadır.

\section{Kaynakça}

\section{Arşiv Kaynakları}

Türkiye Cumhuriyeti Cumhurbaşkanlığı Devlet Arşivleri Başkanlığı Osmanlı Arşivi (BOA)**

Dahiliye Nezareti Asayiş Kalemi (DH. EUM. AYŞ.)

Dahiliye Nezareti Emniyet-i Umumiye Müdüriyeti Üçüncü Şube (DH. EUM. 3. Şb.)

** Arşiv belge numaraları metinde verilmiştir.

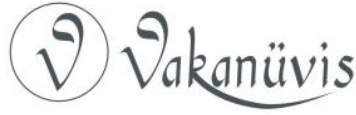


Dahiliye Nezareti Emniyet-i Umumiye Müdüriyeti Altıncı Şube (DH. EUM. 6. Şb.)

Dahiliye Nezareti Şifre Kalemi (DH. ŞFR.)

\section{Süreli Yayınlar \\ Gazeteler \\ Takvim-i Vekayi}

\section{Kitap, Makale ve Tezler}

Alan, Gülbadi, "Anadolu'daki Yabancı Okullar ve Pontusçuluk", Başlangıçtan Günümüze Pontus Sorunu, Ed. Veysel Usta, Serander Yayınları, Ankara 2007, s. 175-198.

Armaoğlu, Fahir, 19. Yüzyıl Siyasî Tarihi (1789-1914), TTK Yayınları, 3. Baskı, Ankara 2003.

, 20 Yüzyıl Siyasî Tarihi (1914-1995), Cilt: 1-2, Alkım Yayınları, 12.

Baskı, İstanbul (Baskı Yılı Yok).

Arşiv Belgeleriyle Ermeni Faaliyetleri 1914-1918, Cilt: I, Haz. Ahmet Tetik, Genelkurmay ATASE ve Genelkurmay Denetleme Başkanlığı Yayınları, Ankara 2005.

Balcıoğlu, Mustafa, “Birinci Dünya Savaşı Sırasında Karadeniz'de Rum Faaliyetleri ve Sivil Tepki", Osmanlı Tarihi Araştırma ve Uygulama Merkezi Dergisi, Sayı: 4, Ankara Üniversitesi Basımevi, Ankara 1993, s. 91-97.

Bayur, Yusuf Hikmet, Türk Inkılâbı Tarihi, Cilt: II/IV, TTK Yayınları, 3. Baskı, Ankara 1991. 1991.

Çapa, Mesut, Pontus Meselesi, Serander Yayınları, Trabzon 2001.

Çiçek, Rahmi, "Merzifon Amerikan Koleji ve Pontus Sorunu”, Başlangıçtan Günümüze Pontus Sorunu, Ed. Veysel Usta, Serander Yayınları, Ankara 2007, s. 199-210.

Duman, Önder, Emperyal Bir Araç Olarak Rum-Pontus Sorunu (1908-1918), Berikan Yayınevi, Ankara 2010.

Goloğlu, Mehmet, Anadolu'nun Millî Devleti Pontos, Kalite Matbaası, Ankara 1973.

Halaçoğlu, Yusuf, Ermeni Tehciri, Babıali Kültür Yayıncılık, 10. Baskı, İstanbul 2007.

Hart, Basil Liddell, Birinci Dünya Savaşı Tarihi, Çev. Kerim Bağrıaçık, Yay. Haz. Edip Gölbaşı-Ülke Evrim Uysal, Türkiye İş Bankası Yayınları, İstanbul 2014.

Karagöz, Rıza "II. Meşrutiyet Döneminde Canik Sancağında İdari Yapılanma", Geçmişten Geleceğe Samsun, Yay. Haz. Cevdet Yılmaz, Samsun

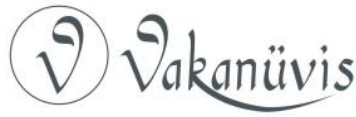


Büyükşehir Belediyesi Kültür ve Eğitim Hizmetleri Daire Başkanlığı Yayınları, Samsun 2006, s. 65-81.

"Canik'in İdarî Yapısı ve İdarecileri", Ilkçağdan Cumhuriyete Canik, Ed: Cevdet Yılmaz, Canik Belediyesi Kültür Yayınları, 2. Baskı, Samsun 2011, s. 119-162.

Karal, Enver Ziya, Osmanlı Tarihi, Cilt: VIII, TTK Yayınları, 4. Baskı, Ankara 1995.

, Osmanlı Tarihi, Cilt: IX, TTK Yayınları, 2. Baskı, Ankara 1999.

Kılıç, Pelin İskender, "Samsun ve Çevresinde Pontus Çetelerinin Faaliyetleri ve Hükümetin Uygulamaları", Turkish Studies, Vol. 6/2, Spring 2011, s. 485502.

Kocaoğlu, Bünyamin, Millî Mücadele Yıllarında 15. Fırkanın Samsun'daki Faaliyetleri (1919-1921), Samsun Büyükşehir Belediyesi Kültür Yayınları 7, 2. Baskı, Samsun 2012.

Küçüker, Yüksel, Tarihî Arka Planıyla Pontus Meselesi ve Yabancı Basına Yansımaları, TTK Yayınları, Ankara 2019.

McCarthy, Justin, Ölüm ve Sürgün, Osmanlı Müslümanlarına Karşı Yürütülen Ulus Olarak Temizleme işlemi 1821-1922, Çev. Bilge Umar, İnkılâp Kitabevi, 6. Baskı, İstanbul 1998.

Okur, Mehmet, "Pontus Meselesinin Ortaya Çıkışı ve Karadeniz Bölgesi'nde Pontusçu Faaliyetleri”, Karadeniz Araştırmaları Dergisi (KARAM), Sayı: 14, Yaz 2007, s. 1-28.

, "Pontus'çu Faaliyetlerde Batılı Devletlerin Rolü", Osmanlı'dan Günümüze Eşkıyalık ve Terör, Ed. Osman Köse, Samsun Illkadım Belediyesi Kültür ve Eğitim Müdürlüğü Yayınları, Samsun 2009, s. 383-397.

Osmanlı Belgelerinde Ermenilerin Sevk ve iskânı (1878-1920), Devlet Arşivleri Genel Müdürlüğü Yayınları Nu: 91, Ankara 2007.

Öz, Mehmet, "Samsun", Türkiye Diyanet Vakfı İslâm Ansiklopedisi, Cilt: 36, Türkiye Diyanet Vakfı Yayın Matbaacılık ve Ticaret İşletmesi, İstanbul 2009, s. 83-88.

Özdemir, Mustafa, “ı. Dünya Savaşı Sırasındaki Osmanlı Devleti Tarafından Gerçekleştirilen Rum Tehciri”, Çağdaş Türkiye Tarihi Araştırmaları Dergisi (ÇTTAD), Cilt: VI/14, İzmir Bahar 2007, s. 27-40.

Pontus Meselesi, Haz. Yılmaz Kurt, TBMM Kültür, Sanat ve Yayın Kurulu Yayınları No: 68, TBMM Basımevi, Ankara 1995.

Roberts, J. M., Avrupa Tarihi, Çev. Fethi Aytuna, İnkılap Kitabevi, İstanbul 2010.

Sarınay, Yusuf, “Pontus Meselesi ve Yunanistan'ın Politikası”, Pontus Meselesi ve Yunanistan'ın Politikası (Makaleler), Yay. Haz. Berna Türkdoğan, Atatürk Araştırma Merkezi, Ankara 2006, s. 1-77.

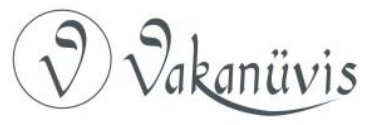


Sezer, Cemal, Ermenilerin Sevk ve İskânı Hakkında Yapılan Uygulama ve Yardımlar (1915-1917), Selçuk Üniversitesi Sosyal Bilimler Enstitüsü (Yayınlanmamış Doktora Tezi), Konya 2011.

Tetik, Ahmet, "Çeteler, Venizelos ve Patrikhane", Başlangıçtan Günümüze Pontus Sorunu, Ed. Veysel Usta, Serander Yayınları, Ankara 2007, s. 211-223.

Tezcan, Mehmet, "Pontos Krallığı (M.Ö. III-M.S. IV Yüzyıl)”, Başlangıçtan Günümüze Pontus Sorunu, Ed. Veysel Usta, Serander Yayınları, Ankara 2007, s. 77-107.

Uçarol, Rifat, Siyasi Tarih (1789-1999), Filiz Kitabevi, 5. Baskı, İstanbul 2000. Yazıcı, Nuri, Millî Mücadele'de Canik Sancağı'nda Pontusçu Faaliyetler (1918-1922), Çizgi Kitabevi, 2. Baskı, Ankara 2003.

Yerasimos, Stefanos, Milliyetler ve Sınırlar Balkanlar, Kafkasya ve OrtaDoğu, İletişim Yayınları, 4. Baskı, İstanbul 2000.

Yolalıcı, M. Emin, XIX. Yüzyılda Canik (Samsun) Sancağı'nın Sosyal ve Ekonomik Yapısı, TTK Yayınları, Ankara 1998. 


\section{EKLER}

Ek 1: Deli Andon'un başında olduğu çetenin Bafra'ya bağlı Engiz köyü civarında Balık gölünde gerçekleştirdikleri katliam hakkında. Bkz. BOA, DH. EUM. 6. Şb., nr. 00055-00027-002-001.

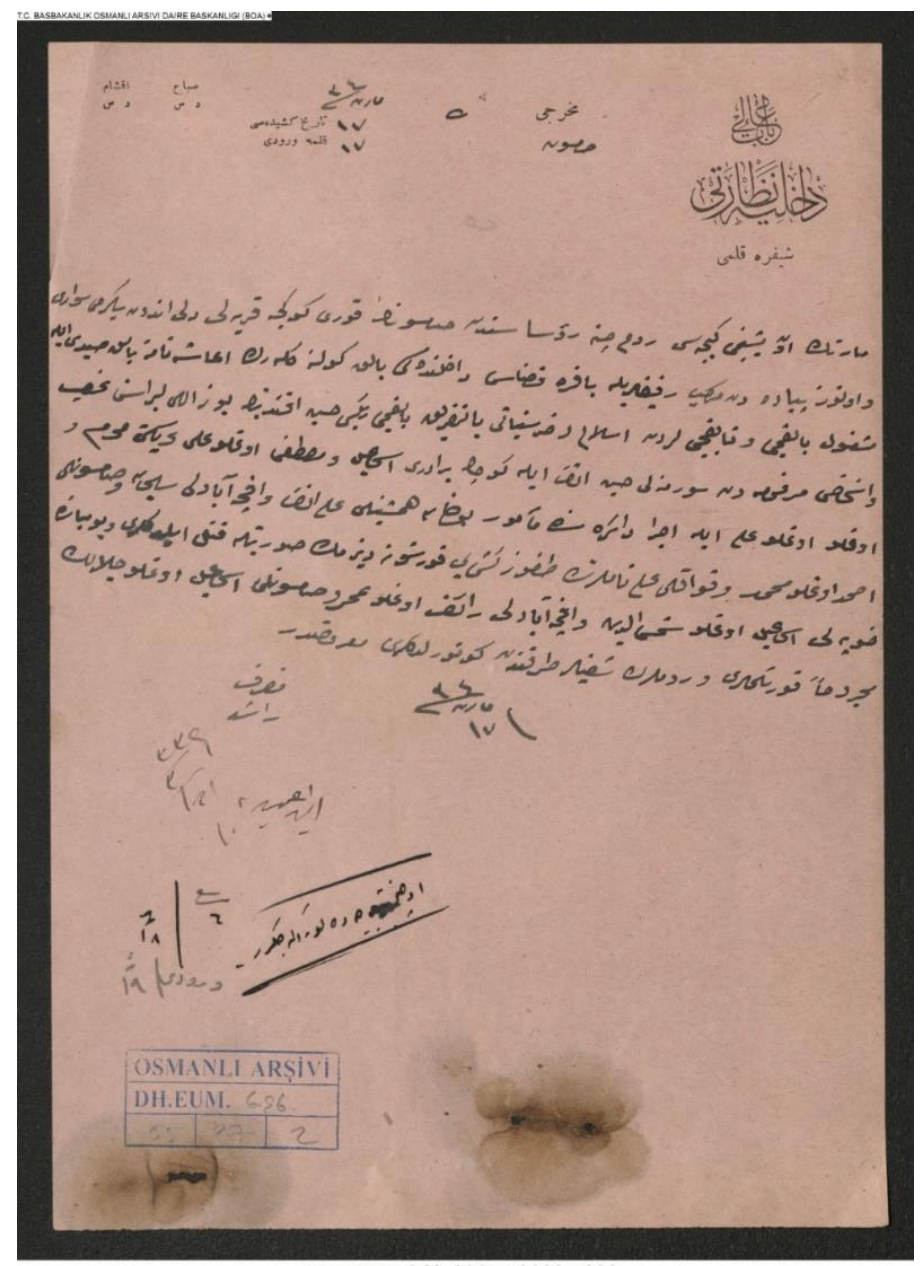

DH.EUM.6.Şb.00055.00027.002

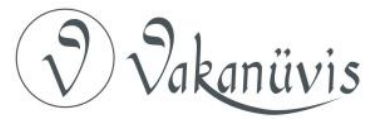


Ek 2: Bafra'dan Kastamonu'nun Çankırı sancağına bağlı Çerkeş kazasına sevk edilen Rumlar hakkında. Bkz. Bkz. BOA, DH. ŞFR., nr. 00554-00002001-001.

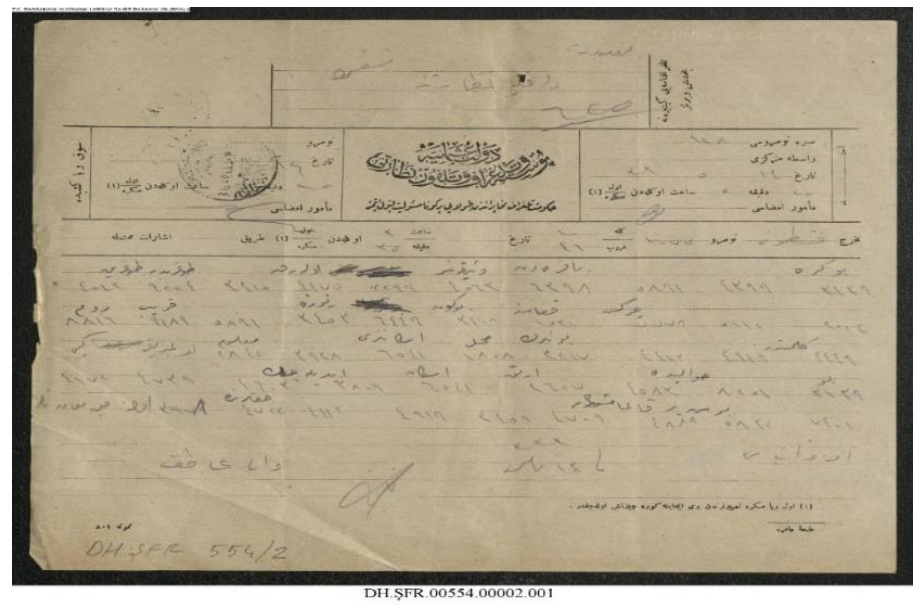

Ek 3: Sinop'un Boyabat kazasına bağlı aynı zamanda Bafra'ya sınır olan Taşağıl köyü ve çevresinde yer alan Pontusçu Rum çetelerinin yerlerini gösteren kroki. Bkz. BOA, DH. EUM. 6. Şb., nr. 00029-00054-002-001.

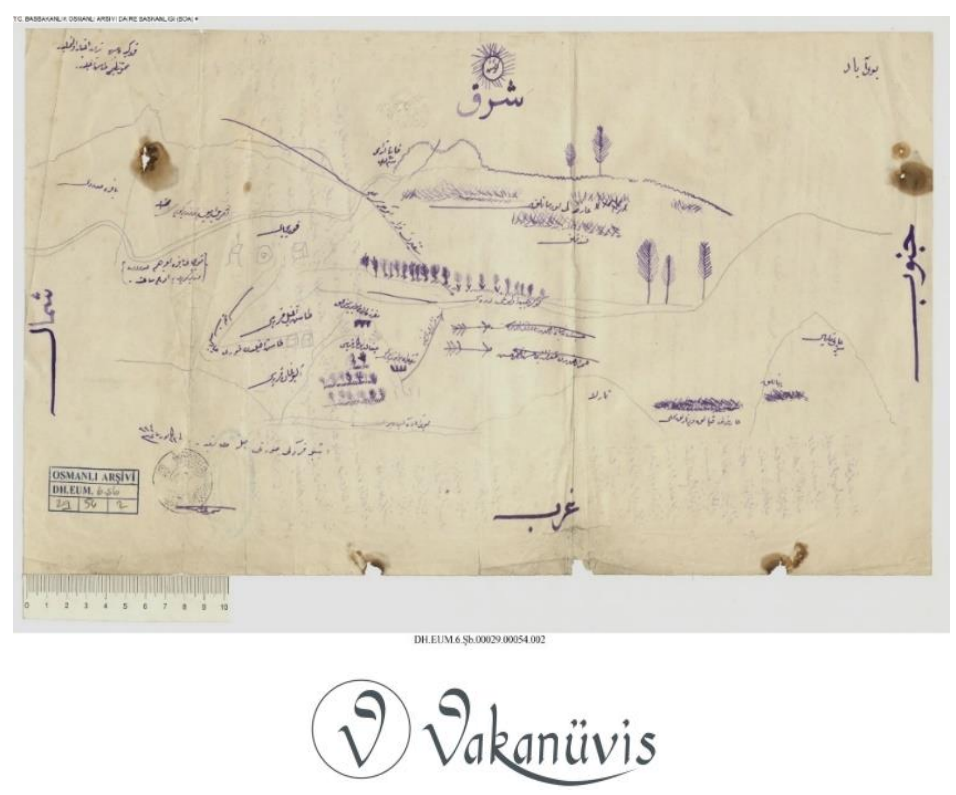

